\title{
Endogenous Protection from Ischemic Brain Injury by Preconditioned Monocytes
}

\author{
Lidia Garcia-Bonilla, David Brea, Corinne Benakis, Diane A. Lane, Michelle Murphy, Jamie Moore, \\ Gianfranco Racchumi, Xinran Jiang, Costantino Iadecola, and Josef Anrather \\ Feil Family Brain and Mind Research Institute, Weill Cornell Medicine, New York, New York 10065
}

Exposure to low-dose lipopolysaccharide (LPS) before cerebral ischemia is neuroprotective in stroke models, a phenomenon termed preconditioning (PC). Although it is well established that LPS-PC induces central and peripheral immune responses, the cellular mechanisms modulating ischemic injury remain unclear. Here, we investigated the role of immune cells in the brain protection afforded by PC and tested whether monocytes may be reprogrammed by ex vivo LPS exposure, thus modulating inflammatory injury after cerebral ischemia in male mice. We found that systemic injection of low-dose LPS induces a $\mathrm{Ly} 6 \mathrm{C}^{\text {hi }}$ monocyte response that protects the brain after transient middle cerebral artery occlusion (MCAO) in mice. Remarkably, adoptive transfer of monocytes isolated from preconditioned mice into naive mice $7 \mathrm{~h}$ after transient MCA0 reduced brain injury. Gene expression and functional studies showed that IL-10, inducible nitric oxide synthase, and CCR2 in monocytes are essential for neuroprotection. This protective activity was elicited even if mouse or human monocytes were exposed ex vivo to LPS and then injected into male mice after stroke. Cell-tracking studies showed that protective monocytes are mobilized from the spleen and reach the brain and meninges, where they suppress postischemic inflammation and neutrophil influx into the brain parenchyma. Our findings unveil a previously unrecognized subpopulation of splenic monocytes capable of protecting the brain with an extended therapeutic window and provide the rationale for cell therapies based on the delivery of autologous or allogeneic protective monocytes in patients after ischemic stroke.

Key words: adoptive transfer; cerebral ischemia; lipopolysaccharide; monocytes; neuroprotection

\section{Significance Statement}

Inflammation is a key component of the pathophysiology of the brain in stroke, a leading cause of death and disability with limited therapeutic options. Here, we investigate endogenous mechanisms of protection against cerebral ischemia. Using lipopolysaccharide (LPS) preconditioning (PC) as an approach to induce ischemic tolerance in mice, we found generation of neuroprotective monocytes within the spleen, from which they traffic to the brain and meninges, suppressing postischemic inflammation. Importantly, systemic LPS-PC can be mimicked by adoptive transfer of in vitro-preconditioned mouse or human monocytes at translational relevant time points after stroke. This model of neuroprotection may facilitate clinical efforts to increase the efficacy of BM mononuclear cell treatments in acute neurological diseases such as cerebral ischemia.

\section{Introduction}

Induction of ischemic tolerance by the exposure to subinjurious stressors, also known as preconditioning (PC), is a powerful mechanism to evoke endogenous neuroprotective programs (Iadecola

Received Feb. 2, 2018; revised June 9, 2018; accepted June 18, 2018.

Author contributions: L.G.-B. and J.A. wrote the first draft of the paper; L.G.-B., D.B., C.B., D.A.L., J.M., G.R., C.I. and J.A. edited the paper; L.G.-B. and J.A. designed research; L.G.-B., D.B., C.B., M.M., J.M., G.R., and X.J. performed research; L.G.-B., D.B., D.A.L., M.M., J.M., G.R., and J.A. analyzed data; L.G.-B. and J.A. wrote the paper.

This work was supported by the National Institutes of Health (Grant NS34179 to C.I. and Grant NS081179 to J.A.), the American Heart Association (Grant 16SDG30970036 to L.G), and the Feil Family Foundation.

The authors declare no competing financial interests.

Correspondence should be addressed to Dr. Josef Anrather, Feil Family Brain and Mind Research Institute, Weill Cornell Medicine, 407 East 61st Street RR409, New York, NY 10065. E-mail: joa2006@med.cornell.edu.

DOI:10.1523/JNEUROSCI.0324-18.2018

Copyright $\odot 2018$ the authors $\quad 0270-6474 / 18 / 386722-15 \$ 15.00 / 0$ and Anrather, 2011). In the brain, PC can be achieved by a variety of agents and stressors, including ischemia, inflammatory mediators, metabolic blockers, anesthetics, cortical spreading depression, and seizures (Kirino, 2002). The immune system plays a key role in the establishment of ischemic tolerance. For example, toll-like receptors (TLRs), key innate immunity receptors, are potent mediators of cerebral PC (Marsh et al., 2009b; Pradillo et al., 2009; Wang et al., 2010; Garcia-Bonilla et al., 2014a) and activation of TLR4 by systemic administration of lipopolysaccharide (LPS) is a potent PC stimulus (Tasaki et al., 1997; Ahmed et al., 2000; Vartanian et al., 2011). However, circulating LPS is impermeable to the blood-brain barrier and does not gain access to the brain (Singh and Jiang, 2004; Banks and Robinson, 2010). Therefore, LPS is thought to induce ischemic tolerance by a sys- 
temic effect involving reprogramming of the immune system (Smith et al., 2002), which in turn protects the brain by suppressing postischemic proinflammatory gene expression, endothelial and microglial activation, as well as leukocyte infiltration (Bauer et al., 2000; Rosenzweig et al., 2004; Lin et al., 2009; Marsh et al., 2009a; Vartanian et al., 2011). However, the cell type(s) on which systemic LPS acts to induce the widespread changes in the immune system underlying the development of cerebral PC remains to be defined.

Monocytes are BM-derived cells characterized by surface expression of CD11b and CD115, which are present in large quantities in the spleen (Swirski et al., 2009). In the circulation, they consist of functionally diverse subsets (Geissmann et al., 2003): Ly6C ${ }^{+} \mathrm{CCR} 2{ }^{+} \mathrm{CX} 3 \mathrm{CR} 1$ low "inflammatory" monocytes, which contribute to the inflammatory process (Swirski et al., 2007; Tacke et al., 2007; Swirski et al., 2010), and Ly6C ${ }^{-}$CCR2 ${ }^{-}$CX3CR1 high "resident" monocytes, which patrol the vasculature and participate in the resolution of inflammation (Auffray et al., 2007; Nahrendorf et al., 2007). A third subset, monocytic myeloid-derived suppressor cells (Serafini et al., 2004; Huang et al., 2006; Bronte, 2009), is present in the BM and shares the same surface markers with inflammatory monocytes (Youn et al., 2008; Ostrand-Rosenberg, 2010; Forghani et al., 2012).

All monocytes subtypes have been implicated in ischemic injury in different organs, in which they can play either protective or destructive roles (Arnold et al., 2007; Nahrendorf et al., 2007, 2010), but their involvement in ischemic PC remains unclear. Considering that monocytes express TLR4 and are a prime target of LPS (Muzio et al., 2000; Biswas and Lopez-Collazo, 2009), it is conceivable that they participate in LPS-PC. Indeed, LPS administration induces BM egress of selected monocyte subtypes such

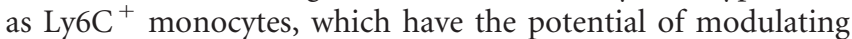
systemic immune responses (Serbina et al., 2008; Shi et al., 2011). Here, we investigated the role of peripheral immune cells in the neuroprotection observed after LPS-PC in mice. We found that LPS treatment induces a Ly6 $\mathrm{C}^{\text {hi }}$ monocyte population of splenic monocytes endowed with a powerful neuroprotective capacity against experimental ischemic brain injury, which is mediated through suppression of meningeal inflammation. The findings highlight a previously unrecognized neuroprotective potential of a distinct monocyte subset and raise the prospect of novel cell-based stroke therapies based on monocyte-induced immunomodulation.

\section{Materials and Methods \\ Mice}

All procedures were approved by the institutional animal care and use committee of Weill Cornell Medicine and were performed in accordance with ARRIVE guidelines (Kilkenny et al., 2011). Experiments were performed in 7- to 8-week-old WT (JAX 000664), inducible nitric oxide synthase KO (iNOS ${ }^{-1-}$; MacMicking et al., 1995), IL-10 ${ }^{-1-}$ (JAX 002251, B6.129P2-Il10tm1Cgn/J), CCR2 ${ }^{\text {RFP/RFP }}$ (JAX017586, B6.129(Cg)-Ccr2tm2. 1Ifc/J), Cox2 $2^{-1-}$ (Morham et al., 1995), or GFP-transgenic (JAX 006567, C57BL/6-Tg(CAG-EGFP)131Osb/LeySopJ) male mice on a C57BL/6J background obtained from The Jackson Laboratory (JAX) and from in-house colonies ( $\mathrm{iNOS}^{-/-}$and Cox $2^{-l-}$ mice).

\section{Middle cerebral artery occlusion (MCAO)}

Transient focal cerebral ischemia was induced using the intraluminal filament model of MCAO as described previously (Jackman et al., 2011). Under isoflurane anesthesia (maintenance 1.5-2\%), the MCA was occluded for $35 \mathrm{~min}$. Reperfusion was confirmed by measuring the cerebral blood flow $(\mathrm{CBF})$ in the MCA territory by transcranial laser Doppler flowmetry (Periflux System 5010; Perimed). Only animals with CBF reduction of $>85 \%$ during $\mathrm{MCAO}$ and $\mathrm{CBF}$ recovered by $>80 \%$ after 10 min of reperfusion were included in the study (Jackman et al., 2011).
Rectal temperature was monitored and kept constant $\left(37.0 \pm 0.5^{\circ} \mathrm{C}\right)$ during the surgical procedure and in the recovery period until the animals regained full consciousness. Topical lidocaine and bupivacaine $(0.25 \%, 0.1$ $\mathrm{ml}$, transdermal) were used for preoperative analgesia and buprenorphine $(0.5 \mathrm{mg} / \mathrm{kg}$ every $24 \mathrm{~h}$, s.c. $)$ as postoperative analgesia for $48 \mathrm{~h}$.

\section{Measurement of infarct volume and neurological deficit}

As described in detail previously (Jackman et al., 2011), blinded assessment of infarct volume, corrected for swelling, was quantified $3 \mathrm{~d}$ after ischemia using Nissl stain on $1230-\mu \mathrm{m}$-thick coronal brain sections using image analysis software (MCID; Imaging Research).

Sensorimotor deficit was assessed $1 \mathrm{~d}$ before and $3 \mathrm{~d}$ after MCAO using the tape test performed by an investigator blinded to the treatment groups (Benakis et al., 2016). Mice were tested at the start of the dark phase of the circadian day/night cycle. Briefly, an adhesive tape was placed on the dorsal aspect of both forepaws. Latency of tape contact with the mouth and tape removal was scored on videos recorded over $180 \mathrm{~s}$. In the test performed $1 \mathrm{~d}$ before MCAO, mice received 3 trials with 10 min rest cycles in between and, on day 3 after MCAO, mice received 2 trials. Results were expressed as time average of tape contact or tape removal latency in each test for the contralesional and lesional side.

\section{LPS in vivo PC}

LPS was repurified from a commercial LPS preparation (Salmonella enterica serotype typhimurium; Sigma-Aldrich; L7261) according to a previously published protocol (Manthey and Vogel, 1994). Mice were injected with either purified LPS ( $0.5 \mathrm{mg} / \mathrm{kg}$, i.p.) or saline (100 $\mu$ l, i.p.) $24 \mathrm{~h}$ before MCAO.

\section{Splenectomy}

Total splenectomy was performed under aseptic conditions and isoflurane anesthesia. Meloxicam ( $2 \mathrm{mg} / \mathrm{kg}$, s.c.) and buprenorphine $(0.5 \mathrm{mg} /$ $\mathrm{kg}$, s.c.) were given for preemptive analgesia. A $1 \mathrm{~cm}$ parasagittal incision was performed through the skin and abdominal musculature and the spleen was exteriorized. Vascular pedicles were ligated using silk suture $(6 / 0)$ and then the splenic artery and vein were transected between the ligation and the spleen, removing the latter. For sham operations, a laparotomy incision was made, but no splenic tissue was resected. Buprenorphine $(0.5 \mathrm{mg} / \mathrm{kg} \mathrm{q} 24 \mathrm{~h}$, s.c.) was given for $48 \mathrm{~h}$ postoperatively. Mice were allowed to recover for $14 \mathrm{~d}$ before undergoing MCAO.

\section{Cell isolation}

Mice were anesthetized with pentobarbital (100 mg/kg, i.p.) and transcardially perfused with heparinized PBS. The spleen was dissected and the head was cut. Next, the skull was cleaned from skin and muscles. The upper portion of the skull was separated from the brain and the meninges (dura/arachnoid) were recovered from the interior of the skull under a dissection microscope. Meninges and spleen were placed on a premoistened $70 \mu \mathrm{m}$ cell strainer and gently homogenized in PBS. Brain cell isolation was performed by mechanical method or enzymatic digestion with Liberase DH (Roche Diagnostics) when cell sorting was performed, as described previously (Garcia-Bonilla et al., 2014b; Benakis et al., 2016). Briefly, for enzymatic brain cell isolation, brain hemispheres were separated from the cerebellum and olfactory bulb and gently triturated in HEPES-HBSS buffer containing the following (in $\mathrm{mM}$ ): 138 $\mathrm{NaCl}, 5 \mathrm{KCl}, 0.4 \mathrm{Na}_{2} \mathrm{HPO}_{4}, 0.4 \mathrm{KH}_{2} \mathrm{PO}_{4}, 5$ D-glucose, and $10 \mathrm{HEPES}$ using a Gentle MACS dissociator (Miltenyi Biotec) following the manufacturer's instructions. The suspension was digested with $62.5 \mu \mathrm{g} / \mathrm{ml}$ Liberase and $50 \mathrm{U} / \mathrm{ml}$ DNase I at $37^{\circ} \mathrm{C}$ for $45 \mathrm{~min}$ in an orbital shaker at $100 \mathrm{rpm}$. For mechanical cell isolation, brain hemispheres were homogenized in RPMI 1640 medium (Mediatech) using a Dounce homogenizer. Brain cells isolated from enzymatic or mechanical procedures were washed and subjected to discontinuous 70/30\% Percoll (GE Healthcare) density gradient centrifugation. Enriched-mononuclear cells were collected from the interphase. BM cells were flushed out from the femurs and tibias and filtered through a $40 \mu \mathrm{m}$ cell strainer. Blood was drained from the submandibular vein into tubes containing sodium heparin and erythrocytes were lysed. Cell suspensions were subsequently stained for flow cytometric analysis. 
Table 1. Antibodies used in the study

\begin{tabular}{|c|c|c|c|c|}
\hline Antigen & Label & Clone & Isotype & Supplier \\
\hline \multicolumn{5}{|c|}{ Antibodies used for cytometric analysis and sorting } \\
\hline CD16/CD32 & & 93 & Rat $\lg G 2 b, \lambda$ & BioLegend \\
\hline CD45 & BV 510 & $30 F-11$ & Rat $\lg G 2 b$ & BioLegend \\
\hline CD11b & $\mathrm{APC} / \mathrm{Cy} 7$ & $\mathrm{M} 1 / 70$ & Rat $\lg \mathrm{G} 2 \mathrm{~b}, \kappa$ & BioLegend \\
\hline CD11C & $\mathrm{PE} / \mathrm{Cy} 7$ & N418 & Armenian hamster lgG & BioLegend \\
\hline Ly6C & FITC & HK1.4 & Rat $\lg G 2 a, \kappa$ & BioLegend \\
\hline Ly6G & PerCP/Cy5.5 & $1 \mathrm{~A} 8$ & Rat $\lg G 2 a, \kappa$ & BioLegend \\
\hline CD115 & $\mathrm{PE}$ & AFS98 & Rat $\lg G 2 a, \kappa$ & BioLegend \\
\hline CD4 & F488 & RM4-5 & Rat $\lg \mathrm{G} 2 \mathrm{a}, \kappa$ & BioLegend \\
\hline $\operatorname{TCR} \beta$ & PerCP/Cy5.5 & H57-597 & Armenian hamster & BioLegend \\
\hline CD8a & $\mathrm{PE} / \mathrm{Cy} 7$ & $53-6.7$ & Rat $\lg G 2 a, \kappa$ & BioLegend \\
\hline $\mathrm{TCR} \gamma \delta$ & $\mathrm{APC}$ & GL3 & Armenian hamster & BioLegend \\
\hline CD19 & $\mathrm{APC} / \mathrm{Cy} 7$ & $6 \mathrm{D} 5$ & Rat $\lg \mathrm{G} 2 \mathrm{a}, \kappa$ & BioLegend \\
\hline CCR2 & APC & 475301 & Rat $\lg G 2 b$ & R\&D System \\
\hline \multicolumn{5}{|c|}{ Antibodies used for monocyte purification by immunodepletion } \\
\hline CD117 & Biotin & $2 \mathrm{~B} 8$ & Rat $\lg \mathrm{G} 2 \mathrm{~b}, \kappa$ & BioLegend \\
\hline CD45R (B220) & Biotin & RA3-6B2 & Rat $\lg \mathrm{G} 2 \mathrm{a}, \kappa$ & BioLegend \\
\hline CD49 & Biotin & HMa2 & Armenian hamster lgG & eBioscience \\
\hline TER 119 & Biotin & TER-119 & Rat $\lg G 2 b, \kappa$ & BioLegend \\
\hline CD5 & Biotin & 37.3 & Rat $\lg G 2 \mathrm{a}, \kappa$ & BioLegend \\
\hline Ly6G & Biotin & $1 \mathrm{~A} 8$ & Rat lgG2a & BioLegend \\
\hline \multicolumn{5}{|c|}{ Antibodies used for neutrophil purification by immunodepletion } \\
\hline CD117 & Biotin & $2 \mathrm{~B} 8$ & Rat $\lg \mathrm{G} 2 \mathrm{~b}, \kappa$ & BioLegend \\
\hline CD45R (B220) & Biotin & RA3-6B2 & Rat $\lg \mathrm{G} 2 \mathrm{a}, \kappa$ & BioLegend \\
\hline CD49 & Biotin & HMa2 & Armenian hamster lgG & eBioscience \\
\hline TER 119 & Biotin & TER-119 & Rat $\lg \mathrm{G} 2 \mathrm{~b}, \kappa$ & BioLegend \\
\hline CD5 & Biotin & 37.3 & Rat $\lg G 2 a, \kappa$ & BioLegend \\
\hline CD115 & Biotin & AFS98 & Rat $\lg \mathrm{G}_{2 \mathrm{a}}$ & BioLegend \\
\hline $\mathrm{F} 4 / 80$ & Biotin & BM8 & Rat $\lg G 2 a, \kappa$ & BioLegend \\
\hline
\end{tabular}

\section{Flow cytometric analysis}

Cells were stained using rat monoclonal antibodies (Table 1) and analyzed on a MACSQuant Analyzer 10 (Miltenyi Biotec). Brain-infiltrating leukocytes were identified as CD $45^{\mathrm{hi}}$ and further gated by CD11b and $\mathrm{CD} 11 \mathrm{c}$ markers. $\mathrm{CD} 45^{\mathrm{hi}} \mathrm{CD} 11 \mathrm{~b}^{-} \mathrm{CD} 11 \mathrm{c}^{+}$were identified as dendritic cells (DCs). From the CD $45{ }^{\text {hi }} \mathrm{CD} 11 \mathrm{~b}^{+} \mathrm{CD} 11 \mathrm{c}^{-}$gate, both monocytes/ macrophages (MMøs) and neutrophils were identified as $\mathrm{CD} 45{ }^{\text {hi }} \mathrm{CD} 11 \mathrm{~b}^{+}$ $\mathrm{CD} 115^{+}$and $\mathrm{CD} 45^{\text {hi }} \mathrm{CD} 11 \mathrm{~b}^{+} \mathrm{Ly}_{6 \mathrm{G}}{ }^{+}$, respectively. MMøs were further separated as $\mathrm{Ly} 6 \mathrm{C}^{\mathrm{hi}}$ or Ly6C $\mathrm{C}^{\mathrm{lo}}$. The same gating strategy was used to phenotype leukocyte in the meninges and peripheral organs. Appropriate isotype controls, "fluorescence minus one" staining, and staining of negative populations were used to establish sorting parameters. Absolute cell numbers and frequencies were recorded. Samples were acquired and analyzed by an investigator blinded to the treatment groups.

\section{Fluorescence activated cell sorting}

Brain cells isolated by the enzymatic procedure were stained for CD45, CD115, Ly6G, and Ly6C as described above. Leukocytes isolated from brains of mice injected with LPS or saline that did not undergo MCAO were identified as CD $45^{\mathrm{hi}}$ and further gated by CD115 and Ly6G and Ly6C markers. "Inflammatory" or "resident" MMøs, identified as CD45 hi CD $115^{+}$Ly6G $^{-}$Ly6C $^{\text {hi }}$ or Ly6C ${ }^{\text {lo }}$, respectively, were sorted on a FACSVantage cytometer (BD Biosciences) and collected in TRIzol LS (Invitrogen) for transcriptomic profiling. Brains from three to four mice were pooled.

\section{Monocyte and neutrophil isolation by immunodepletion from BM}

BM was flushed out from femurs and tibias and cells were dispersed by aspiration through a 20 gauge needle. After erythrolysis, BM cells were resuspended in MACS buffer (PBS supplemented with 2\% FBS, 2 mM EDTA; $100 \mu \mathrm{l} / 10^{7}$ cells). Cells were incubated with a biotinylated antibody mixture (Table 1) and purified with anti-biotin microbeads according to the manufacturer's instructions (Miltenyi Biotec). Afterward, cells were washed, resuspended in sterile physiological saline $\left(5 \times 10^{6}\right.$ cells/ $\mathrm{ml}$ ), and administered by retroorbital injection (intraveous) in anesthe- tized mice. Cell preparations contained $>90 \%$ Ly $6 \mathrm{C}^{\text {hi }}$ monocytes as determined by flow cytometry analysis. Neutrophils were also purified from mouse BM of LPS-preconditioned animals by immunomagnetic negative enrichment essentially as described above with a different biotinylated antibody mixture (Table 1). Cell preparations contained $>90 \%$ neutrophils as determined by flow cytometry (anti-Ly6G-PerCP-Cy5.5, clone 1A8; BioLegend).

\section{Generation of BM-derived macrophages (BMMs) and myeloid-derived suppressor cells (MDSCs)}

Generation of BMMs, classically activated macrophages (CAMs), or alternatively activated macrophages (AAMs) was conducted as described previously (Weischenfeldt and Porse, 2008) with modifications. After erythrocyte lysis, isolated $\mathrm{BM}$ cells were resuspended $\left(1 \times 10^{6}\right.$ cells $\left./ \mathrm{ml}\right)$ in BM medium (DMEM/F12, 10\% FBS, 20\% L929-conditioned medium, $100 \mathrm{U} / \mathrm{ml}$ penicillin, and $100 \mu \mathrm{g} / \mathrm{ml}$ streptomycin) and cultured in $5 \% \mathrm{CO}_{2}$ at $37^{\circ} \mathrm{C}$ for $7 \mathrm{~d}$. Fresh medium was added every $2-3 \mathrm{~d}$. Polarization to CAM was induced by $100 \mathrm{U} / \mathrm{ml}$ IFN- $\gamma$ (PeproTech) for $48 \mathrm{~h}$ and $10 \mathrm{ng} / \mathrm{ml} \mathrm{LPS}$ for the last $24 \mathrm{~h}$. AAMs were obtained by incubating BMMs with $10 \mathrm{ng} / \mathrm{ml}$ recombinant murine IL-4 (R\&D Systems) for $24 \mathrm{~h}$. Fully differentiated adherent macrophages were washed twice with warm DMEM/F12 and collected by detaching them with a stream of ice-cold DMEM/F12 containing 10\% FBS. Cells were collected by centrifugation and resuspended in sterile saline $\left(5 \times 10^{5}\right.$ cells/100 $\left.\mu \mathrm{l}\right)$. MDSCs were generated according to a previously published protocol (Highfill et al., 2010). Briefly, isolated BM cells were cultured in MDSC medium (DMEM, 10\% FBS, 10 mM HEPES, $1.5 \mathrm{~mm}$ L-arginine, $1.5 \mathrm{~mm}$ L-asparagine, $1.5 \mathrm{~mm}$ L-glutamine, and $0.05 \mathrm{~mm} \beta$-mercaptoethanol) in the presence of recombinant murine granulocyte macrophage colony-stimulating factor $(250$ $\mathrm{U} / \mathrm{ml}$; BioLegend) and granulocyte colony-stimulating factor (100 ng/ $\mathrm{ml}$; Peprotech) for $4 \mathrm{~d}$. IL-13 (BioLegend) was added $(80 \mathrm{ng} / \mathrm{ml})$ on day 3. Cells were harvested at day 4 and MDSCs were isolated from each culture by immunomagnetic positive selection using anti-CD11b-PE antibody, anti-PE magnetic microbeads, and LS column separation (Miltenyi Biotec). The purity of isolated cell populations was found to be $>90 \%$ by flow cytometry. Suppressor function was tested for inhibition of splenic $\mathrm{CD}^{+}{ }^{+} \mathrm{T}$-cell proliferation in the presence of anti-CD3 and antiCD28 antibodies (see Fig. 4B).

\section{Transcriptomic profiling}

Total RNA was extracted from sorted Ly6C ${ }^{\text {hi }}$ brain MMøs for analysis of gene expression by Illumina Mouse WG-6 version 2.0 Expression BeadChips. Total RNA was amplified with TargetAmp-Nano Labeling Kit for Illumina Expression BeadChip (Epicenter). All procedures were conducted according to the manufacturer's instructions by the Genomics Shared Resource supported by Roswell Park Cancer Institute and National Cancer Institute Grant P30CA016056. Data were checked for quality with Illumina's GenomeStudio gene expression module version 1.9.0. Summary data were background subtracted and normalized by variance stabilization using the beadarray (version 2.20.2) (Dunning et al., 2007) and limma (version 3.26.8) (Ritchie et al., 2015) packages within the R statistical environment (version 3.2.3). Analysis of differential expression was conducted in limma for probe sets filtered by spot detection $(p<$ $0.05)$ and difference in mean signal intensity between treatment groups (difference $>4$ ). Significantly changed genes were subjected to analysis of canonical pathways curated by DAVID Functional Annotation Bioinformatics Microarray Analysis (Sherman et al., 2007). Heat maps were generated in GenePattern (Reich et al., 2006) using genes selected by the differential gene expression analysis. Expression data have been deposited for public access in the National Center for Biotechnology Information Gene Expression Omnibus under accession number GSE84327.

\section{qRT-PCR}

Quantitative determination of gene expression was examined as described prevously (Garcia-Bonilla et al., 2015). Total RNA was extracted from ischemic hemispheres and meninges using TRIzol reagent. The RNeasy Plus Mini Kit (Qiagen) was used to extract RNA from BM cells. Next, cDNA was synthetized with iScript reverse transcription supermix 
Table 2. Primer sequences used for qRT-PCR

\begin{tabular}{|c|c|}
\hline Gene & Sequence \\
\hline \multirow[t]{2}{*}{$\operatorname{Arg} 1$} & $5^{\prime}$-CATCAACACTCCCCTGACAAC-3' \\
\hline & 5'-GTACACGATGTCTTTGGCAGA-3 \\
\hline \multirow[t]{2}{*}{$\mathrm{CCl} 2$} & 5'-AGGTGTCCCAAAGAAGCTGTA-3' \\
\hline & 5'-ATGTCTGGACCCATTCCTTCT-3' \\
\hline \multirow[t]{2}{*}{$\mathrm{C} 15$} & 5'-ATATGGCTCGGACACCACTC-3' \\
\hline & $5^{\prime}$ - GTGACAAACACGACTGCAAGA-3' \\
\hline \multirow[t]{2}{*}{ Chi3/3 } & 5'-AGGCTGCTACTCACTTCCACA-3' \\
\hline & 5'-TTTTCTCCAGTGTAGCCATCC-3' \\
\hline \multirow[t]{2}{*}{ Csf1 } & 5'-TGAGTCTGTCTTCCACCTGCT- $3^{\prime}$ \\
\hline & $5^{\prime}-$ - CCCACAGAAGAATCCAATGTC-3' \\
\hline \multirow[t]{2}{*}{ Csf2 } & 5'-AGCTCTGAATCCAGCTTCTCA-3' \\
\hline & 5'-TGGTCCCTTTAAGGCAGAAAT-3' \\
\hline \multirow[t]{2}{*}{ Csf3 } & 5'-AGTGTTCCCAAACTGGGTTCT-3' \\
\hline & 5'-TTAGGGACTTCGTTCCTGTGA-3' \\
\hline \multirow[t]{2}{*}{ Cxd1 } & $5^{\prime}$-GCGAAAAGAAGTGCAGAGAGA-3' \\
\hline & $5^{\prime}$-AAACACAGCCTCCCACACAT-3' \\
\hline \multirow[t]{2}{*}{ Cxc15 } & 5'-TGAGAAGGCAATGCTGTCAT-3' \\
\hline & $5^{\prime}$-CCAGGCTCAGACGTAAGAACA-3' \\
\hline \multirow[t]{2}{*}{ Stab } & 5'-CTGAAAGCTTCGGCTACAAGA \\
\hline & 5'-TTCTTTCTATCAGGAGGCAAGG-3' \\
\hline \multirow[t]{2}{*}{ Cxcl10 } & 5'-ATCACTCCCCTTTACCCAGTG-3' \\
\hline & $5^{\prime}$-GGAGGAGTAGCAGCTGATGTG-3' \\
\hline \multirow[t]{2}{*}{ Cxcl12 } & 5'-GTCTAAGCAGCGATGGGTTC-3' \\
\hline & 5'-TAGGAAGCTGCCTTCTCCTG-3' \\
\hline \multirow[t]{2}{*}{ Hprt } & $5^{\prime}$-AGTGTTGGATACAGGCCAGAC-3' \\
\hline & 5'-CGTGATTCAAATCCCTGAAGT-3' \\
\hline \multirow[t]{2}{*}{$\|-10$} & 5'-TGGAGCAGGTGAAGAGTGATT-3' \\
\hline & $5^{\prime}$-CACACTGCAGGTGTTTTAGCTT-3' \\
\hline \multirow[t]{2}{*}{ Nos2 } & 5'-TCACCACAAGGCCACATCGGATT-3' \\
\hline & 5'-AGCTCCTCCAGAGGGGTAGGCT-3' \\
\hline \multirow[t]{2}{*}{ Retnla } & 5'-TCCTGGAACCTTTCCTGAGAT-3' \\
\hline & $5^{\prime}$-GATGCAGATGAGAAGGGAACA-3' \\
\hline
\end{tabular}

for qRT-PCR (Bio-Rad). qRT-PCR was conducted with cDNA in duplicate reactions using the Maxima SYBR Green/ROX qPCR Master Mix $(2 \times)$ (Thermo Scientific). The reactions were incubated at $50^{\circ} \mathrm{C}$ for 2 min and then at $95^{\circ} \mathrm{C}$ for $10 \mathrm{~min}$. A PCR cycling protocol consisting of $15 \mathrm{~s}$ at $95^{\circ} \mathrm{C}$ and $1 \mathrm{~min}$ at $60^{\circ} \mathrm{C}$ for 45 cycles was used for quantification. Primer sequences (Invitrogen) are described in Table 2. Data were expressed as relative fold change over sham-operated control mice calculated by the $2^{-\Delta \Delta \mathrm{Ct}}$ method (Livak and Schmittgen, 2001).

\section{Histology}

Histology of whole-mount meninges was performed as described previously (Louveau and Kipnis, 2015) with some modifications. Mice were anesthetized with sodium pentobarbital and perfused transcardially with ice-cold PBS followed by $4 \%$ paraformaldehyde (PFA) in PBS. Brains were extracted from the skull and the skullcap was postfixed in $4 \%$ PFAPBS overnight. Next, the meninges (dura/arachnoid) were washed with PBS and dissected from the skull under a surgical microscope. Whole meninges were permeabilized with $0.5 \%$ Triton X-100 (Sigma-Aldrich) in PBS (PBST) for $30 \mathrm{~min}$, blocked with 5\% normal donkey serum (NDS) in $0.1 \%$ PBST for $1 \mathrm{~h}$, and incubated with anti-collagen IV (1:400, rabbit polyclonal; \#ab6586; Abcam, RRID:AB_305584) antibody for $2 \mathrm{~h}$ in 1\%NDS-0.1\% PBST. The meninges were washed with $0.1 \%$ PBST, incubated with Cy5conjugated secondary antibody (1:200; Jackson ImmunoResearch Laboratories), and mounted on slices using ProLong Gold Antifade mountant with DAPI (Thermo Fisher Scientific). All staining procedures were performed at room temperature. Immunostaining was visualized by epifluorescent (Olympus IX83) or confocal (Leica TCS SP5) microscopy.

Dissected brains and spleens were postfixed in 4\% PFA-PBS overnight at $4^{\circ} \mathrm{C}$, immersed in $30 \%$ sucrose solution, and frozen. Coronal brain sections and transverse sections of the spleen were cut (16 $\mu \mathrm{m}$ thickness) using a cryostat and mounted on slides. For nuclear staining, spleen and brain sections were permeabilized with $0.5 \%$ PBST and then incubated with TO-PRO-3 iodide (Thermo Fisher Scientific) for $30 \mathrm{~min}$ at room temperature. For brain immunostaining, coronal sections were permeabilized with $0.5 \%$ PBST, blocked with 5\% normal donkey serum (NDS), and incubated with antibodies against the endothelial cell marker glucose transporter 1 (GLUT-1; 1:200, rabbit polyclonal antibody; Calbiochem), the microglia/macrophage marker ionized calcium binding adaptor molecule 1 (Ibal; 1:500, rabbit polyclonal antibody; Wako Chemicals), and transforming growth factor beta (TGF- $\beta$ ) cytokine $(1: 200$; catalog \#MAB1835, RRID:AB_357931) in 1\% NDS-0.1\% PBST at $4^{\circ} \mathrm{C}$ overnight. After 310 min washes with $0.1 \%$ PBST, brain slices were incubated with a Tetramethylrhodamine (TRITC)- or a Cy5-conjugated secondary antibody (1:200; Jackson ImmunoResearch Laboratories). Slices were washed with $0.1 \%$ PBST, mounted with FluorSave Reagent (Millipore), and visualized by confocal microscopy.

\section{Arginase and NOS activity}

Arginase activity was assayed essentially as described previously (Corraliza et al., 1994). Briefly, $1 \times 10^{5}$ isolated BM monocytes from saline or LPS-treated mice $(24 \mathrm{~h}$ ) were lysed in $50 \mu \mathrm{l}$ of $0.1 \%$ Triton X-100 containing pepstatin, aprotinin, and antipain and incubated on a shaker for $30 \mathrm{~min}$ at room temperature. The enzyme was activated after adding 50 $\mu \mathrm{l}$ of $10 \mathrm{~mm} \mathrm{MnCl}_{2}, 50 \mathrm{~mm}$ Tris- $\mathrm{HCl}, \mathrm{pH} 7.5$, at $55^{\circ} \mathrm{C}$ for $10 \mathrm{~min}$. After addition of equal volume of $0.5 \mathrm{~m}$ arginine, $\mathrm{pH} 9.7$, arginine hydrolysis was performed at $37^{\circ} \mathrm{C}$ for $60 \mathrm{~min}$. Reactions were stopped by acidification and the urea formed was colorimetrically quantified at $540 \mathrm{~nm}$ after addition of $\alpha$-isonitrosopropiophenone and heating at $100^{\circ} \mathrm{C}$ for $45 \mathrm{~min}$. NOS activity was assessed by measuring nitrite production. Briefly, isolated BM monocytes were resuspended in RPMI 1640 supplemented with $10 \% \mathrm{FBS}$ and penicillin/streptomycin at a density of $5 \times 10^{5} \mathrm{cells} / \mathrm{ml}$ and restimulated with $100 \mathrm{U} / \mathrm{ml}$ IFN- $\gamma$ and $100 \mathrm{ng} / \mathrm{ml} \mathrm{LPS} \mathrm{for} 24 \mathrm{~h}$ at $37^{\circ} \mathrm{C}$ in a humidified atmosphere containing $5 \% \mathrm{CO}_{2}$. Nitrite in supernatants was determined by the Griess reaction according to the manufacturer's suggestions (Promega, catalog \#g2930).

\section{IL-10 protein level determination}

IL-10 production in isolated BM monocytes was measured by ELISA (Thermo Fisher Scientific, catalog \#BMS614/2, RRID:AB_2575685). Briefly, isolated BM monocytes were incubated in RPMI 1640 supplemented with $10 \% \mathrm{FBS}$ and penicillin/streptomycin and restimulated with 100 $\mathrm{ng} / \mathrm{ml}$ LPS for $16 \mathrm{~h}$ at $37^{\circ} \mathrm{C}$ in a humidified atmosphere containing $5 \%$ $\mathrm{CO}_{2}$. Secreted IL-10 was assayed in cell culture supernatants.

\section{Experimental design and statistical analysis}

Adoptive transfer of in vivo-preconditioned monocytes

A first study was performed to test whether the transfer of isolated monocytes from LPS-PC mice induces neuroprotection in mice that undergo MCAO. To this end, monocytes were purified by immunodepletion from BM cells of 7- to 8-week-old WT mice treated with saline or LPS $(0.5 \mathrm{mg} / \mathrm{kg}$ in $100 \mu \mathrm{l}$ saline, i.p.) $24 \mathrm{~h}$ previously. A different researcher blinded to the surgical procedures injected the isolated monocytes $\left(5 \times 10^{5}\right.$ cells in $100 \mu \mathrm{l}$ of sterile saline/mouse, i.v.) into mice at different time points before or after MCAO. The mice were randomly allocated to receive either LPS or saline monocytes. The infarct volume was analyzed $72 \mathrm{~h}$ after MCAO to assess brain damage and compared with mice that received either saline or LPS (intraperitoneally) or that received adoptively transferred neutrophils $\left(5 \times 10^{5}\right.$ cells in $100 \mu \mathrm{l}$ of sterile saline/mouse, i.v. $)$.

A second study was conducted to test whether iNOS, IL-10, CCR2, or Cox 2 molecules are important in conferring the protective effect of the monocytes. In these experiments, monocytes were purified by immunodepletion from BM cells of 7- to 8-week-old WT, iNOS ${ }^{-1-}, \mathrm{IL}_{-10^{-1-}}$, CCR2 $2^{\text {RFP/RFP }}$, or Cox $2^{-1-}$ mice treated with saline or LPS $(0.5 \mathrm{mg} / \mathrm{kg}$ in $100 \mu \mathrm{l}$ saline, i.p.) $24 \mathrm{~h}$ previously. The monocytes were injected $\left(5 \times 10^{5}\right.$ cells in $100 \mu \mathrm{l}$ of sterile saline/mouse, i.v.) into mice $7 \mathrm{~h}$ after MCAO. Infarct volumes were analyzed $72 \mathrm{~h}$ after MCAO.

\section{Adoptive transfer of BMMs and MDSCs}

A third study was conducted to assess whether BMMs that underwent classical (CAM) or alternative (AAM) activation and MDSCs also have 
the capacity to provide neuroprotection to mice undergoing MCAO when adoptively transferred. Mice were randomly allocated to receive BMMs, CAMs, AAMs, or MDSCs $\left(5 \times 10^{5}\right.$ cells in $100 \mu$ l of sterile saline/mouse, i.v.) $7 \mathrm{~h}$ after MCAO. An investigator blinded to surgical procedures conducted macrophage transfers. Infarct volumes were analyzed $72 \mathrm{~h}$ after MCAO.

Adoptive transfer of ex vivo-preconditioned monocytes

In a forth study, we tested the translational potential of transferring monocytes that were ex vivo treated with LPS into mice undergoing MCAO. In these experiments, mouse monocytes isolated from BM of 7- to 8-weekold naive mice as described above and human peripheral blood monocytes (79\% CD14 ${ }^{+} \mathrm{CD} 16^{\text {low }}$ cells) purchased from Lifeline Cell Technology were incubated with purified LPS $(100 \mathrm{ng} / \mathrm{ml})$ or vehicle (PBS) in RPMI with $10 \%$ FBS $\left(2 \times 10^{6}\right.$ cells $\left./ \mathrm{ml}\right)$ at $37^{\circ} \mathrm{C}$ and $5 \% \mathrm{CO}_{2}$ for $2 \mathrm{~h}$. Next, the monocytes were washed, resuspended in sterile saline, and injected $(5 \times$ $10^{5}$ cells $/ 100 \mu \mathrm{l}$ of saline, i.v.) into mice $7 \mathrm{~h}$ after MCAO. Mice were randomly allocated to LPS or PBS ex vivo monocyte groups. An investigator blinded to surgical procedures and monocyte treatment performed monocyte transfer experiments. Infarct volumes were analyzed $72 \mathrm{~h}$ after MCAO.

\section{Role of the spleen in the protection afforded by}

preconditioned monocytes

A fifth study was conducted to determine the splenic contribution to the neuroprotective effect exerted by preconditioned monocytes. In a first substudy, we performed tracking experiments of labeled monocytes to investigate whether preconditioned monocytes have a splenic origin. In a second substudy, we tested whether the protection afforded by preconditioned monocytes is lost in mice without spleen.

Experiments of substudy 1 . To investigate whether monocytes mobilize from the spleen after LPS-PC, splenic monocytes were labeled with fluorescent latex beads. To this end, intraabdominal surgery was conducted to inject $50 \mu \mathrm{l}\left(3.64 \times 10^{10}\right.$ particles/ml $)$ of Fluoresbrite Yellow Green Microspheres (0.50 $\mu \mathrm{m} \varnothing$; Polysciences) into the mouse spleen capsule $7 \mathrm{~h}$ after saline or LPS treatment. Mice were anesthetized under isoflurane (maintenance 1.5-2\%) and shaved on the middle left side of the abdomen. A $1.0 \mathrm{~cm}$ parasagittal incision was made to enter in the peritoneal cavity and exteriorize the spleen to perform the fluorescent latex $\left(\mathrm{Lx}^{+}\right)$injection. Meloxicam ( $2 \mathrm{mg} / \mathrm{kg}$, s.c.) and buprenorphine $(0.5 \mathrm{mg} /$ $\mathrm{kg}$, s.c.) were given for preemptive analgesia. Splenic and mobilized fluorescent $\mathrm{Lx}^{+}$monocytes to blood, brain, and meninges were quantified $24 \mathrm{~h}$ after LPS by flow cytometry. Moreover, $\mathrm{GFP}^{+}$-expressing monocytes were ex vivo treated with LPS and transferred $\left(5 \times 10^{5}\right.$ cells in 100 $\mu \mathrm{l}$ of sterile saline/mouse, i.v.) into mice $7 \mathrm{~h}$ after MCAO. Mice were allowed to survive for 24,48 , and $72 \mathrm{~h}$ relative to MCA occlusion. Histological analysis of spleen, BM, lymph nodes, lungs, brain, and meninges was conducted to map the location of mobilized $\mathrm{GFP}^{+}$MMøs.

Experiments of substudy 2. After total splenectomy or sham surgery (sham group), mice were allowed to recover for $14 \mathrm{~d}$ and then randomly assigned to LPS or saline intraperitoneal injection before MCAO. Infarct volume was evaluated $72 \mathrm{~h}$ after MCAO. In separate groups, MCAO was induced in either splenectomized or sham mice $14 \mathrm{~d}$ after surgery. Ex vivo LPS-treated monocytes $\left(5 \times 10^{5}\right.$ cells in $100 \mu$ l of sterile saline/mouse, i.v.) were injected into stroke mice $7 \mathrm{~h}$ after reperfusion. Infarct volume was evaluated $72 \mathrm{~h}$ after MCAO.

\section{Statistical analysis}

Data were analyzed using GraphPad Prism version 7 software. Intergroup differences were assessed for parametric data (Shapiro-Wilk normality test) by Student's $t$ test, one-way ANOVA, or two-way ANOVA followed by post hoc tests as appropriate. For nonparametric data, MannWhitney or Kruskal-Wallis test was used. Data are expressed as mean \pm SEM and differences were considered statistically significant $p<0.05$ at a $95 \%$ confidence level.

\section{Results}

LPS-PC increases Ly6 $\mathrm{C}^{\text {hi }}$ MMøs in brain and meninges

First, we sought to determine whether administration of neuroprotective doses of LPS (Tasaki et al., 1997; Marsh and Stenzel-
Poore, 2008) leads to an increase in immune cells in the CNS. LPS administration induced the recruitment of MMøs to the brain compared with mice receiving saline (Fig. $1 A, D$ ). The increase was observed $24 \mathrm{~h}$ after LPS and was sustained for at least $72 \mathrm{~h}$, a time window consistent with the protective effect afforded by LPS-PC (Rosenzweig et al., 2007). Although neutrophils (Ly6G ${ }^{+}$ cells) increased 3.7-fold in the blood $24 \mathrm{~h}$ after LPS (Fig. $1 B$ ), they were increased in the brain only at $24 \mathrm{~h}$, an effect that did not reach statistical significance (Fig. $1 D$ ). To determine the localization of LPS-induced MMøs within the brain, we conducted histological analysis in animals after intravenous administration of $\mathrm{Lx}^{+}$. Histological analysis showed that $\mathrm{Ibal}^{+} \mathrm{Lx}^{+}$MMøs displayed an amoeboid morphology and intermediate Ibal expression. They were found in the parenchyma as well within cortical vessels making tight contact with the endothelium (Fig. 1C). These findings also indicate that LPS-PC leads to entry of circulating monocytes into the brain.

We then investigated whether the brain-associated MMøs were of the "inflammatory" (Ly6C $\left.{ }^{\text {hi }}\right)$ or "resident" $\left(\right.$ Ly6C $\left.^{\text {lo }}\right)$ phenotype. Ly6C ${ }^{\text {hi }}$ MMøs were significantly higher in brains $24 \mathrm{~h}$ after LPS compared with saline (Fig. $1 E$ ). This was not correlated with an increase in the peripheral blood, in which the number of CD $115^{+}$Ly6C $^{\text {hi }}$ cells after LPS was not different from saline controls (Fig. 1E). In addition to the brain, CD115 ${ }^{+} \mathrm{Ly}_{6 \mathrm{C}}{ }^{\text {hi }}$ cells also increased in the meninges $24 \mathrm{~h}$ after LPS treatment (Fig. 1F), whereas no change in meningeal neutrophils was observed (Fig. $1 F$ ). Nonmyeloid immune cells in brain and meninges were not affected by LPS-PC (data not shown). Therefore, LPS administration leads to accumulation of predominantly CD $115^{+}{\text {Ly } 6 C^{\text {hi }}}^{-}$ MMøs in the brain and meninges.

\section{Adoptive transfer of monocytes from preconditioned donors protects naive mice from ischemic brain injury}

Having established that LPS-PC leads to accumulation of CD115 ${ }^{+}$ Ly6C ${ }^{\text {hi }}$ MMøs to brain and meninges, we investigated whether these cells contribute to the neuroprotection observed after LPSPC. To this end, we isolated BM monocytes $24 \mathrm{~h}$ after LPS or saline administration and transferred them into naive mice undergoing MCAO (Fig. 2A). More than $90 \%$ of immunopurified BM monocytes were Ly6C ${ }^{\text {hi }}$ (Fig. $2 B$ ). Adoptive transfer of monocytes $\left(5 \times 10^{5}\right.$ cells, i.v. $)$ from LPS-treated mice $7 \mathrm{~h}$, but not $24 \mathrm{~h}$, after MCAO resulted in a reduction in infarct volume similar to that of mice receiving LPS $24 \mathrm{~h}$ before MCAO (Fig. 2C,D). Adoptive transfer of monocytes $24 \mathrm{~h}$ before MCAO resulted in partial protection that was not statistically significant (Fig. 2D). Monocytes isolated from mice $24 \mathrm{~h}$ after saline administration did not elicit neuroprotection when adoptively transferred to naive mice $7 \mathrm{~h}$ after MCAO (Fig. 2E). Similarly, adoptive transfer of neutrophils isolated from the BM of LPS-treated mice did not confer neuroprotection after adoptive transfer into naive hosts $7 \mathrm{~h}$ after MCAO (Fig. 2E). These findings indicate that Ly6C ${ }^{\text {hi }}$ monocytes isolated from LPS-treated mice and transferred into naive mice reproduce in full the protective effect of LPS-PC.

\section{Transcriptomic profiling of protective monocytes}

Next, we investigated whether LPS-induced brain-associated monocytes exhibit a gene expression profile different from those of saline-treated animals. Transcriptomic profiling of brain MMøs identified 270 genes that were upregulated ( $>4$-fold) in MMøs isolated from the brains of LPS-treated animals compared with MMøs from saline controls, whereas 414 were downregulated (Fig. 3A). Upregulated genes were associated with immune and inflammatory responses, regulation of GTPase activity and cho- 
A
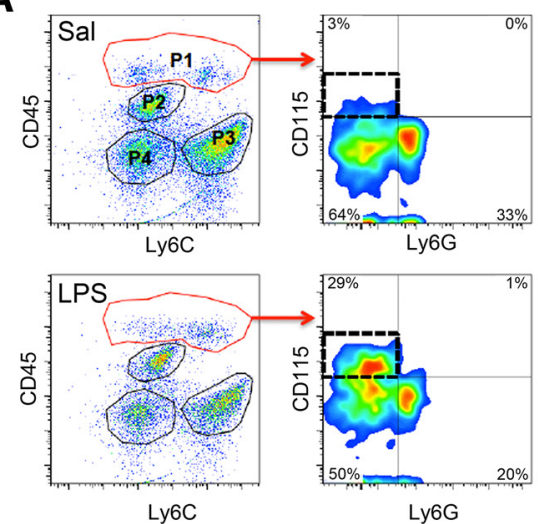

B

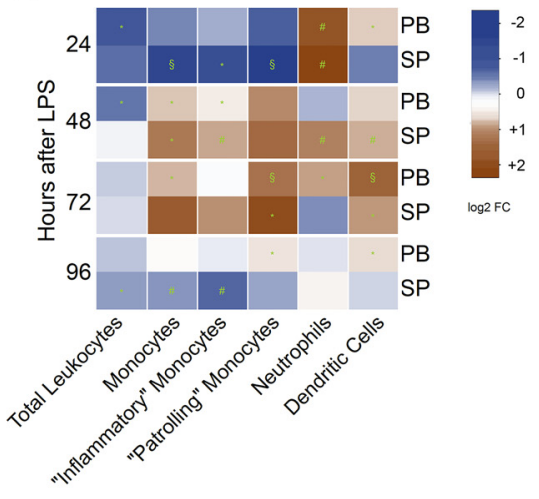

C

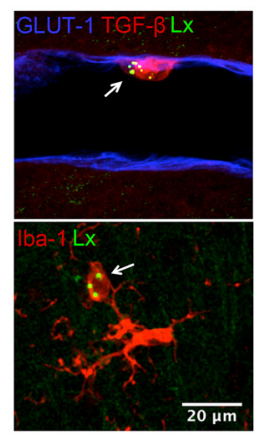

D
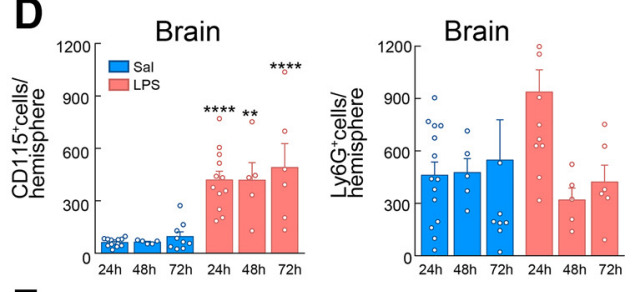

E
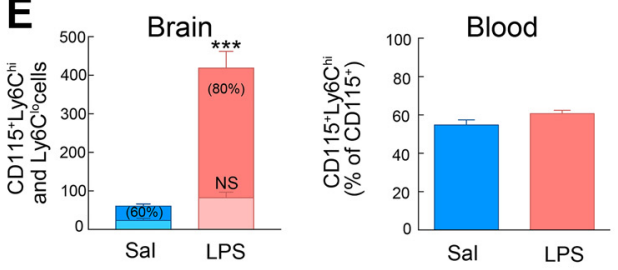

$\mathbf{F}$
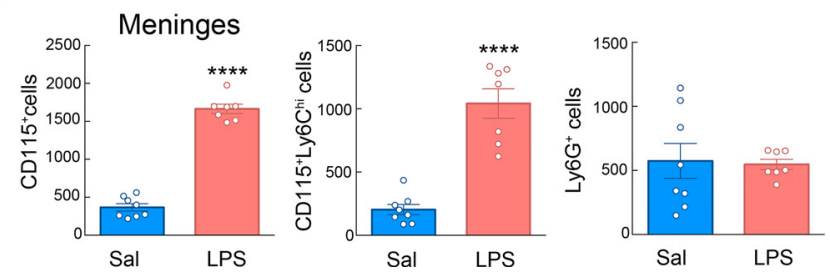

Figure 1. Systemic LPS-PC induces selective recruitment of inflammatory monocytes to brain and meninges. $A$, Flow cytometry analysis of isolated brain cells separated P1, P2, P3, and P4 populations based on CD45 and Ly6C expression. P1 identified infiltrating brain leukocytes (CD45 $\left.{ }^{\text {hi }}\right) 24 \mathrm{~h}$ after LPS injection ( $0.5 \mathrm{mg} / \mathrm{kg}$, i.p.); $\mathrm{P} 2$ corresponded to microglia (CD $\left.45^{\text {int }} \mathrm{Ly} 6 \mathrm{C}^{-}\right)$; $\mathrm{P3}$ identified endothelial cells (CD45 ${ }^{-}$Ly6C $^{+}$); and P4 corresponded to CD45 ${ }^{-}$Ly6C ${ }^{-}$cells. Further analysis of CD115 and Ly6G expression on infiltrating leukocytes (P1) identified recruited monocytes $\left(\mathrm{CD} 45^{\mathrm{hi}} \mathrm{CD} 115^{+} \mathrm{Ly6G}^{-}\right)$and neutrophils $\left(\mathrm{CD} 45^{\text {hi }} \mathrm{CD} 115^{-} \mathrm{Ly6G}^{+}\right)$. An increase of infiltrating MMøs was observed in LPS-treated mice compared with saline-injected mice. $\boldsymbol{B}$, Heat map analysis of leukocyte numbers in peripheral blood (PB) or spleen (SP) from LPS-treated mice over saline-injected mice. Frequencies of leukocyte populations were calculated for each tissue at $24,48,72$, or $96 \mathrm{~h}$ after treatment. $\log _{2}$ fold change was calculated for LPS over saline for each endpoint. Statistical analysis: unpaired two-tailed Student's $t$ test, ${ }^{*} p<0.05$; $\# p<0.01$; $\S p<0.001$. C, Representative images of CD115 ${ }^{+} \mathrm{Lx}^{+}$cells in the brain. Top image shows an $\mathrm{Lx}^{+}$monocyte (green), stained for TGF- $\beta$ (red), in close association to GLUT1-positive (blue) endothelial cells. Bottom image shows an Lx ${ }^{+}$(green) and Iba1intermediate (red) monocyte cell next to lba1-high microglia with stellate morphology. $D, C D 115^{+}$cells quantification in the brain indicated a sustained increase of MMøs in LPS-treated mice during the first $72 \mathrm{~h}$ after LPS injection. A transient increase in the Ly6G ${ }^{+}$cell number was observed at $24 \mathrm{~h}$ in LPS-injected mice, although statistical changes were not found in brain neutrophils between saline and LPS treatment over the first $72 \mathrm{~h}(n=5-14$ mice/group). Statistical analysis: two-way ANOVA (interaction, $F_{(2,44)}=0.07020, p=0.9323$; time, $F_{(2,44)}=0.4909, p=0.6154$; treatment, $F_{(1.44)}=55.76, p<0.0001$ ) followed by Sidak's post hoc test, ${ }^{* *} p<0.05 ;{ }^{* * * *} p<0.000$. E, Left, Quantification of the total cell number of brain CD115 ${ }^{+}$Ly6C ${ }^{\text {hi }}$ (dark color) and $\mathrm{CD}_{115}{ }^{+} \mathrm{Ly}_{6 \mathrm{C}}{ }^{\text {lo }}$ (light color) in saline- or LPS-treated mice $24 \mathrm{~h}$ after treatment. The percentage of CD115 ${ }^{+} \mathrm{Ly}_{6 \mathrm{C}}{ }^{\text {hi }}$ of the total CD115 ${ }^{+}$is given in brackets. Right, Percentage of blood inflammatory monocytes (CD115 ${ }^{+}$Ly6 $\left.6 C^{\text {hi}}\right)$ in saline- or LPS-treated mice $24 \mathrm{~h}$ after treatment ( $n=12-13$ mice/group). Increased Ly6 $\mathrm{C}^{\text {hi }}$ number of MMøs was observed in the brains of LPS-treated mice. Statistical analysis: two-way ANOVA (interaction, $F_{(1,46)}=31.16, p<0.0001$; treatment, $F_{(1,46)}=69.33, p<0.0001$; subpop-

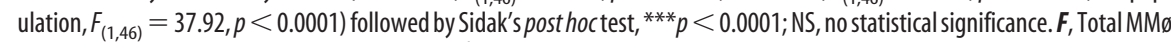
$\left(\mathrm{CD} 115^{+}\right)$and inflammatory $\mathrm{MM} \varnothing\left(\mathrm{CD} 115^{+} \mathrm{Ly6C}{ }^{\mathrm{hi}}\right)$ number was increased in meninges of mice $24 \mathrm{~h}$ after either saline $(n=8)$ or LPS $(n=7)$ injection. Neutrophils (Ly6G $\left.{ }^{+}\right)$did not change. Statistical analysis: unpaired two-tailed Student's $t$ test $(t=16.93$, $\left.\mathrm{df}=13,{ }^{* * * *} p<0.0001\right)$ for total CD115 ${ }^{+}$cells; unpaired two-tailed Student's $t$ test $\left(t=7.207 \mathrm{df}=1,{ }^{* * * *} p<0.0001\right)$ for CD115 ${ }^{+}$Ly6C hi cells. lesterol homeostasis, whereas downregulated genes included members of cell adhesion, cell proliferation, positive transcriptional regulation, and angiogenesis pathways (Fig. 3B). Genes associated with alternative macrophage polarization were highly upregulated, including $I L-10$ and arginase 1 (Fig. 3C). IL-10 and Arginase 1 (Arg1) mRNA, as assessed by RT-PCR, were also increased in monocytes isolated from the BM of LPS-treated mice (Fig. $3 D)$, in which a corresponding increase in IL-10 protein expression and arginase enzymatic activity was also observed (Fig. 3E). Moreover, iNOS (Nos2) mRNA, a gene involved in LPS-PC (Kawano et al., 2007; Kunz et al., 2007), was also upregulated in $\mathrm{BM}$ monocytes isolated from LPS-treated mice (Fig. 3D) and was associated with increased NO production (Fig. 3E). Other genes linked to AAMs, such as YM1 (Chi3l1), Fizz1/RELM $\alpha$ (Retnla), and stabilin 1 (Stab1), were also upregulated (Fig. $3 F)$. Therefore, the "protective" monocytes induced by LPS administration express selected genes typical of AAMs.

\section{Unlike monocytes, macrophages and} MDSCs are not neuroprotective

Given that AAMs have been observed in the brain after ischemia and could be beneficial due to their anti-inflammatory activity (Miró-Mur et al., 2016), we compared the neuroprotective ability of LPS-induced monocytes with that of BMMs that underwent classical (CAM) or alternative (AAM) activation. In addition, we assessed the protective capacity of MDSCs, a myeloid cell population with strong anti-inflammatory activity upregulated in the periphery after stroke ( $\mathrm{Se}$ rafini et al., 2004; Huang et al., 2006; Bronte, 2009; Liesz et al., 2015). To this end, we generated CAMs, AAMs, and MDSCs from BMMs in vitro by exposing BMMs to IFN- $\gamma /$ LPS, IL-4, or IL-4/IL-13, respectively (Weischenfeldt and Porse, 2008; Highfill et al., 2010). Successful polarization was confirmed by monitoring the mRNA expression of genes associated with the respective subpopulations including Arg1, IL-10, Nos2, Retnla, Chi3l3, and Stab1 (Fig. 4A). MDSCs were tested for their ability to suppress $\mathrm{CD} 4{ }^{+} \mathrm{T}$-cell proliferation (Fig. 4B). All in vitrogenerated macrophage populations expressed CCR2, a chemokine receptor needed for macrophage entry into the brain and association with meninges (Fig. $4 C)$. Cells $\left(5 \times 10^{5}\right)$ were then adoptively transferred to mice $7 \mathrm{~h}$ after MCAO and infarct volumes were determined $72 \mathrm{~h}$ later. We found that none of the in vitro- 
A

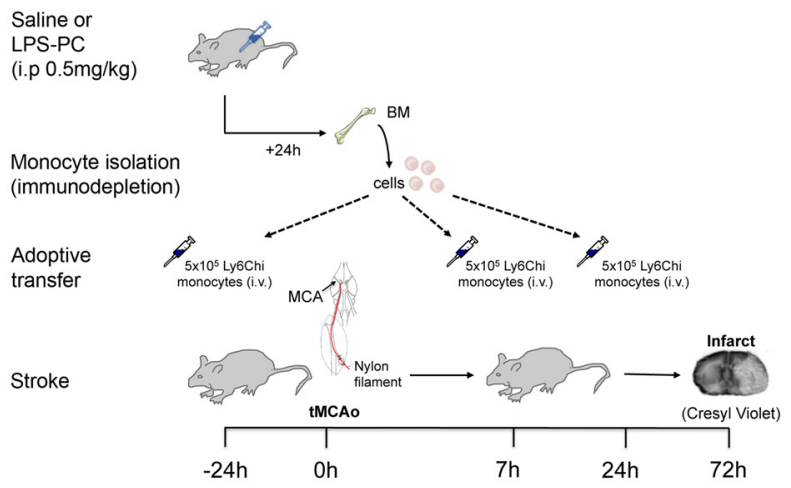

B

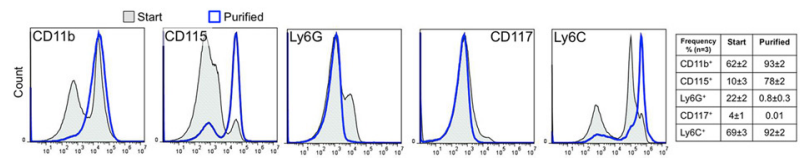

C

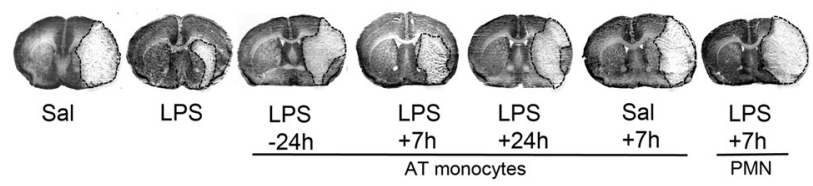

D

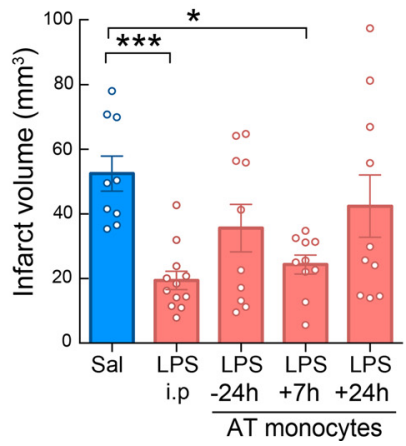

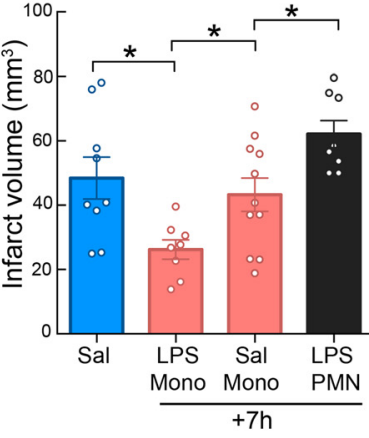

Figure 2. Adoptive transfer of LPS-primed monocytes isolated from preconditioned donors decreases infarct volume in stroke recipient mice. $\boldsymbol{A}$, Experimental design for adoptive transfer of monocytes in stroke mice. Mice were injected with either LPS or saline and monocytes were isolated from BM by immunodepletion $24 \mathrm{~h} \mathrm{later}$. Saline or LPS monocytes $\left(5 \times 10^{5}\right.$ monocytes $\left./ 100 \mu l\right)$ were injected intravenously into stroke mice $24 \mathrm{~h}$ before transient MCAO or 7 or $24 \mathrm{~h}$ after MCA0. Infarct volume was determined by cresyl violet staining $72 \mathrm{~h}$ after MCA0. B, Isolated BM cells were stained for CD11b, CD115, Ly6G, CD117, and Ly6C markers before (start) and after (purified) immunodepletion. Stained cells were assayed by flow cytometry. Monocytes were isolated with high purity as evidenced by the expression of CD11b, CD115, and Ly6C markers and lack of expression of the neutrophil marker Ly6G and the hematopoietic stem cell marker CD117. C, Representative images of brain infarcts in saline-injected mice (SAL), LPS-preconditioned mice (LPS), or mice that received monocytes isolated from LPS-preconditioned mice $24 \mathrm{~h}$ before MCA0 ( $-24 \mathrm{~h}$ ) or 7 or $24 \mathrm{~h}$ after $\mathrm{MCAO}(+7 \mathrm{~h}$ and $+24 \mathrm{~h}$, respectively). Mice that received monocytes from saline-injected mice are indicated as SAL $+7 \mathrm{~h}$ and mice that received neutrophils isolated from $\mathrm{LPS}$-injected mice are indicated as PMN $+7 \mathrm{~h}$. The infarct (pale areas) is outlined in brain coronal sections stained with cresyl violet $72 \mathrm{~h}$ after MCA0. AT, Adoptive transfer. $\boldsymbol{D}$, Infarct volume was significant smaller in either LPS-preconditioned mice (LPS i.p.) or in mice receiving adoptively transferred LPS-monocytes at $+7 \mathrm{~h}(n=9-12)$. Statistical analysis: Kruskal-Wallis (H $=15.65, p=0.0035)$ followed by Dunn's post hoc test. ${ }^{*} p<0.05 ;{ }^{* * *} p<0.001$. E, Adoptive transfer of monocytes isolated from saline-injected mice or neutrophils (PMN) from LPS-preconditioned mice at $+7 \mathrm{~h}$ after MCA0 did not reduce infarct volumes $(n=8-11)$. Statistical analysis: one-way ANOVA $F_{(3,32)}=7.747, p=0.0006$, followed by Holm-Sidak's post hoc test, ${ }^{*} p<0.05$.

differentiated BMM populations reduced infarct volume after adoptive transfer (Fig. 4D). Therefore, unlike LPS-induced protective monocytes, CAMs, AAMs, and MDSCs are unable to ameliorate ischemic brain injury.

\section{iNOS, IL-10, and CCR2 are required for the beneficial effect of monocytes}

Because Nos 2 and $I L-10$ gene expression was upregulated in LPSinduced monocytes, we investigated whether iNOS or IL-10 was required for their neuroprotective effects. To this end, BM monocytes isolated from iNOS ${ }^{-1-}$ or IL-10 ${ }^{-1-}$ LPS-treated mice were adoptively transferred $\left(5 \times 10^{5}\right.$ cells $)$ to WT mice $7 \mathrm{~h}$ after MCAO and infarct volume was determined $72 \mathrm{~h}$ later. Neither $\mathrm{iNOS}^{-1-}$ nor IL-10 ${ }^{-1-}$ monocytes induced neuroprotection compared with LPS-induced WT monocytes (Fig. 4E). Because CCR2 is required for the recruitment of "inflammatory" monocytes to sites of ischemic inflammation (Swirski et al., 2009; Garcia-Bonilla et al., 2016), we adoptively transferred monocytes from CCR $2^{-1-}$ mice treated with LPS (Fig. $4 E$ ). We found that CCR2 ${ }^{-1-}$ monocytes failed to induce neuroprotection, suggesting that monocyte migration to the brain and/or meninges is required for the protection. In contrast, LPS-induced monocytes isolated from mice deficient for the inflammatory enzyme cyclooxygenase-2 (COX2) were able to protect from ischemic brain injury, attesting to the specificity of iNOS, IL-10, and CCR2 in the protective effect.

\section{Trafficking of protective monocytes to spleen, meninges, and brain}

Next, we investigated the potential source of the protective MMøs in mice undergoing LPS-PC. Because we observed a significant depletion of splenic monocytes $24 \mathrm{~h}$ after LPS-PC, whereas blood monocytes were not changed (Fig. $1 B$ ), we tested whether monocytes are mobilized from the spleen and recruited to the brain and meninges. The spleen is a monocyte reservoir that can be mobilized after ischemia in other organs (Swirski et al., 2009) and splenic monocytes have been implicated in stroke pathology (Seifert et al., 2012; Dotson et al., 2015; Kim et al., 2014). To specifically label phagocytes in the spleen, $\mathrm{Lx}^{+}$beads $(0.5 \mu \mathrm{m}$ diameter) were injected into the spleen of mice $7 \mathrm{~h}$ after they were treated with either saline or LPS. Eighteen hours later, histological examination of the spleen revealed that $\mathrm{Lx}^{+}$beads distributed throughout the subcapsular sinus and the red pulp (Fig. 5A). Flow cytometric analysis showed efficient uptake of $\mathrm{Lx}^{+}$beads by splenic CD $115^{+} \mathrm{Ly}_{6 \mathrm{G}}{ }^{-}$MMøs in LPS- and salinetreated animals (Fig. 5B,C). However, $\mathrm{Lx}^{+}$monocytes were found in blood and MMøs in bthe rain and meninges in LPStreated animals, but not saline controls, indicating that LPS-PC mobilizes splenic monocytes that are then recruited to brain and meninges (Fig. $5 B, C$ ).

To gain an insight into the trafficking of adoptively transferred protective monocytes, we isolated BM monocytes from mice ubiquitously expressing GFP treated with LPS $24 \mathrm{~h}$ earlier and transferred them to WT mice $7 \mathrm{~h}$ after MCAO. Histological analysis of spleen, brain, and meninges was performed $24 \mathrm{~h}$ after MCAO. In contrast to monocytes in mice treated with LPS (Fig. $5 B, C$ ), adoptively transferred $\mathrm{GFP}^{+}$monocytes were found in the spleen and meninges, but not the brain parenchyma (Fig. 5D). The transfer to the meninges required CCR 2 because CCR $2^{-1-}$ monocytes did not efficiently migrate to the meninges (Fig. $5 E$ ); therefore, the spleen and meninges are major sites of monocyte/MMø localization both in LPS-preconditioned mice and in mice adoptively transferred with monocytes from LPS-treated mice undergoing MCAO. 

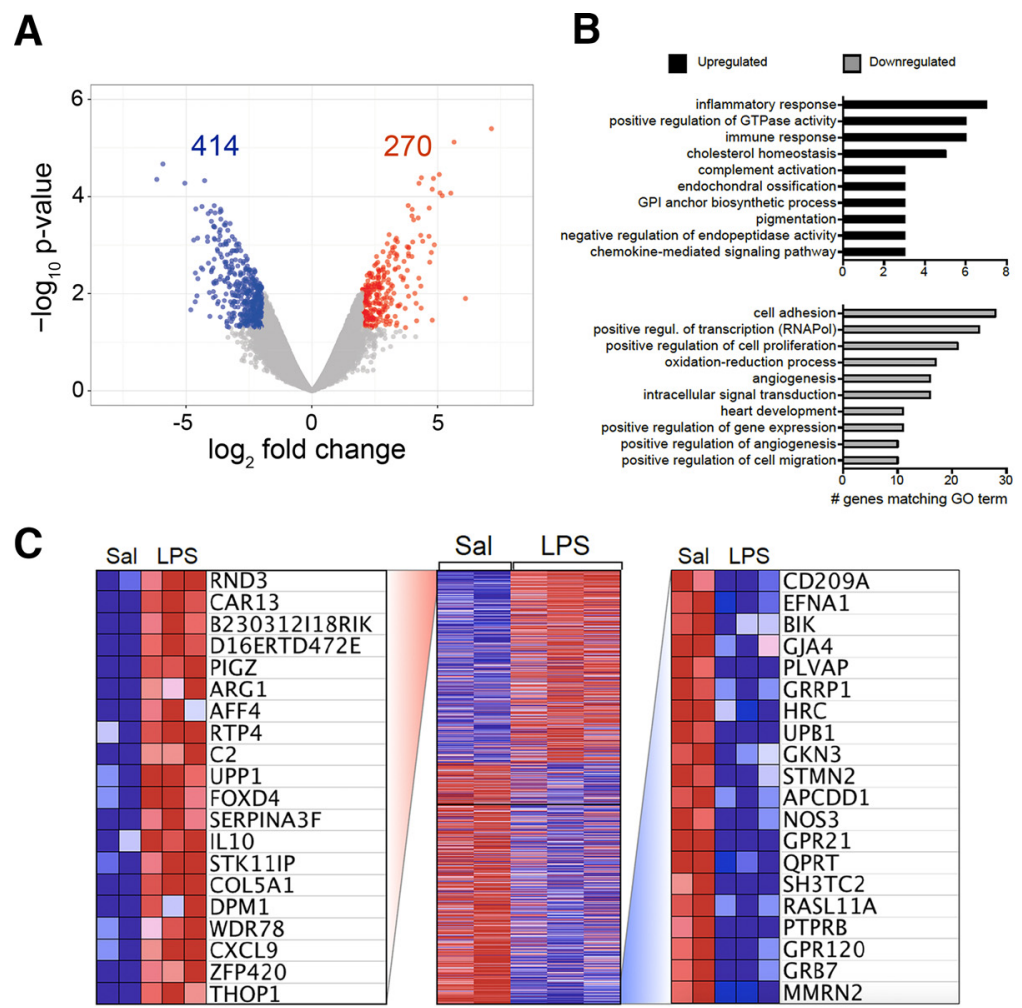

Upregulated

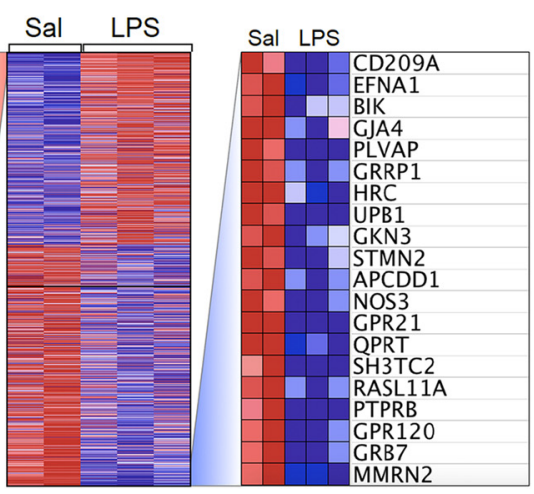

Downregulated
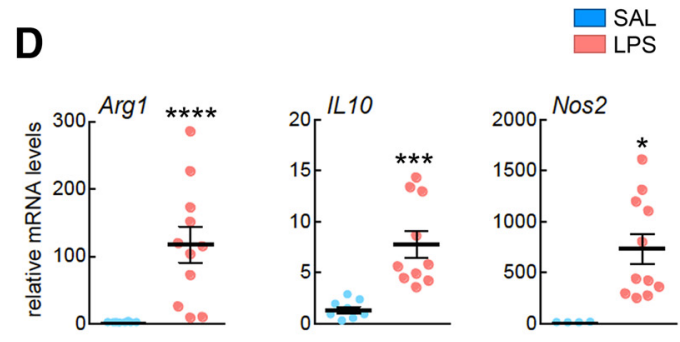

\section{$E$}
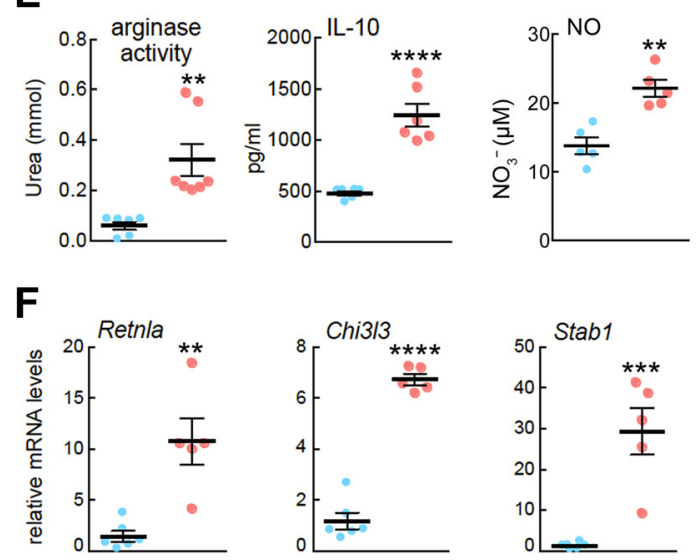

Figure 3. Transcriptomic analysis of brain-associated monocytes from LPS-preconditioned mice. $\boldsymbol{A}, \log _{2}$ fold-change versus $p$-value plot of microarray data analysis of gene expression in isolated brain MMøs from LPS-preconditioned mice over saline-treated mice ( $n=2-3, n=8-12$ ), highlighting downregulated genes (blue, $<4$-fold) and upregulated genes (red, $>4$-fold). $\boldsymbol{B}$, Gene Ontology (GO) analysis of gene expression revealed upregulation of genes associated with immune and inflammatory response, regulation of GTPase activity, and cholesterol homeostasis and downregulation of genes that are members of cell adhesion, cell proliferation, positive transcriptional regulation, and angiogenesis pathways. $C$, Heat map showing the top 20 genes upregulated and the top 20 genes downregulated in LPS versus saline (SAL)-treated mice. D, Quantification of Arg1, IL-10, and iNOS gene (Nos2) expression by qRT-PCR in mouse BM monocytes. Monocytes were isolated $24 \mathrm{~h}$ after LPS or SAL injection. Data are expressed as relative $n$-fold changes over SAL group. Arg1, IL-10, and Nos 2 mRNA were significantly upregulated in LPS-primed monocytes. Statistical analysis: Arg1, Mann-Whitney test $\left(U=0,{ }^{* * * *} p<0.0001\right)$; IL-10, Mann-Whitney test $\left(U=0,{ }^{* * * *} p<0.0001\right)$; Nos2, unpaired tw0-tailed Student's $t$ test $\left(t=2.895\right.$, df $\left.=13,{ }^{*} p=0.0125\right)$. $\boldsymbol{E}$, Quantification of arginase activity by determination of urea, IL-10 protein level by ELISA assay, and iNOS activity by Griess reaction showing increased activities or protein level in BM monocytes of LPS-preconditioned mice compared with BM monocytes of saline-treated mice. Statistical analysis: urea, Mann-Whitney test $\left(U=0,{ }^{* *} p<0.0012\right)$; IL-10, unpaired two-tailed Student's $t$ test $\left(t=6.749, \mathrm{df}=10,{ }^{* * * *} p<0.0001\right)$; N0, unpaired two-tailed Student's $t$ test $\left(t=4.83, \mathrm{df}=8,{ }^{* *} p=0.0013\right)$, respectively. $\boldsymbol{F}$, Quantification of genes associated with alternatively activated macrophage polarization showing upregulated mRNA levels in BM monocytes isolated $24 \mathrm{~h}$ after LPS treatment over saline treatment. Statistical analysis: Retnla, unpaired two-tailed Student's $t$ test $(t=4.371$, $\left.\mathrm{df}=9,{ }^{* *} p=0.0018\right)$; Chi313, unpaired two-tailed Student's $t$ test $\left(t=13.71, \mathrm{df}=9,{ }^{* * * *} p<0.0001\right)$, Stab1, unpaired two-tailed Student's $t$ test $\left(t=5.426\right.$, df $=9$, $\left.{ }^{* * *} p=0.0004\right)$.

\section{Role of the spleen in the neuroprotection afforded by LPS-PC monocytes}

In view of the above results supporting a splenic source of preconditioned monocytes, we next investigated whether the spleen is required in the ischemic neuroprotection triggered by monocytes. To this end, mice underwent surgery to remove their spleens and, $14 \mathrm{~d}$ after recovery, splenectomized mice were treated with LPS or saline intraperitoneally $24 \mathrm{~h}$ before MCAO induction. Analysis of their infarct volumes $72 \mathrm{~h}$ later showed similar large infarcts in both LPS- and saline-treated splenectomized mice, indicating that LPS-PC did not induce neuroprotection after splenectomy (Fig. $5 F$ ). Moreover, ex vivo LPS-PC monocytes were adoptively transferred into either splenectomized mice or sham-operated mice undergoing $7 \mathrm{~h}$ of MCAO (Fig. 5G). Adoptive transfer of LPS monocytes decreased the infarct volume in sham-operated mice, but not in splenectomized mice. These data reveal that a significant loss in monocytic protection is observed in mice without spleens.

\section{LPS-PC results in increased meningeal and decreased brain immune cell accumulation after stroke}

We then investigated whether the presence of PC-induced MMøs in brain and meninges has an impact on the postischemic infil- tration of inflammatory cells in brain. Mice underwent LPS or saline treatment $24 \mathrm{~h}$ before stroke and the cell populations in brain and meninges were assessed $48 \mathrm{~h}$ after MCAO, a time point when peripheral immune cell infiltration is maximal (GarciaBonilla et al., 2014b; Benakis et al., 2016). Although MMøs were increased in the meninges of LPS-PC mice compared with saline treated controls (Fig. 6A), brain MMø were unchanged (Fig. 6B). In contrast, the number of neutrophils was not different in the meninges between groups, but brain-infiltrating neutrophils were reduced in LPS-PC mice (Fig. $6 A, B$ ). CD4 ${ }^{+}$T cells, CD8 ${ }^{+}$ $\mathrm{T}$ cells, $\gamma \delta \mathrm{T}$ cells, $\mathrm{B}$ cells, and NK cells trended lower without reaching statistical significance (data not shown). Together, these data indicate that PC-induced MMøs in the meninges are associated with reduced neutrophil trafficking into the brain after a stroke.

\section{Ex vivo treatment with LPS induces a neuroprotective} phenotype in mouse and human monocytes

Although our results are consistent with a direct effect of LPS on monocytes leading to a protective phenotype, indirect activation by downstream effectors induced by LPS such as proinflammatory cytokines, lipid mediators, or DAMPs cannot be excluded. To address whether LPS acts directly on monocytes, we exposed monocytes isolated from naive animals to LPS (100 ng/ml, $2 \mathrm{~h}$ ) or 
A
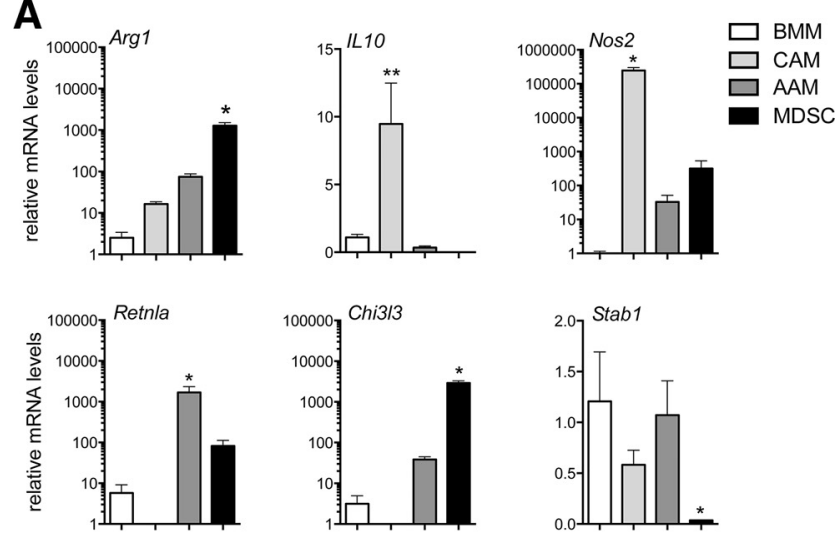

B

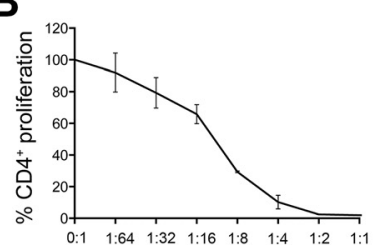

MDSC : $\mathrm{CD}^{+}$

D

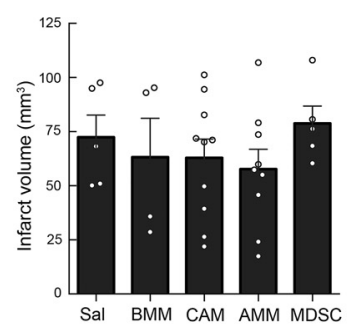

C

E

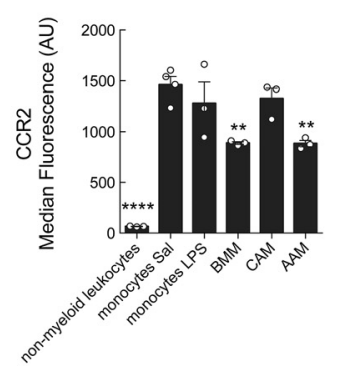

Figure 4. IL-10, iNOS, and CCR2 are required for the neuroprotection induced by LPS-primed monocytes. A, Quantification of Arg1, IL-10, iNOS (Nos2), Retnla, Chi3/3, and Stab1 gene expression in cultured BMMs, classical or alternative activated BMMs (CAMs and AAMs, respectively), and MDSCs by qRT-PCR. Statistical analysis: Kruskal-Wallis followed by Dunn's test versus BMMs; $\operatorname{Arg} 1(\mathrm{H}=8.291$, $p=0.0013),{ }^{*} p=0.05 ; / L-10(H=10.97, p<0.0001),{ }^{* *} p=0.01 ; \operatorname{Nos} 2(H=9.859, p=0.003)$, ${ }^{*} p=0.05$; Retnla $(H=9.929, p=0.0012),{ }^{*} p=0.05 ; C h i 3 / 3(H=10.24, p=0.006),{ }^{*} p=0.05$; Stab1 $\left(H=7.750,{ }^{*} p=0.0286\right),{ }^{*} p=0.05 ; n=3-4 /$ group. $B$, Increment cell numbers of splenic $\mathrm{CD} 4{ }^{+}$cells were stimulated with anti-CD3 and anti-CD28 antibodies in the presence of MDSCs. Percentage of $\mathrm{CD} 4{ }^{+}$T-cell proliferation was calculated to assess suppressor function $(n=2) \cdot x$-axis values represent MDSC/splenic CD4 ${ }^{+}$cell ratio. C, Quantification of the median fluorescence of CCR2 signal analyzed by flow cytometry of in nonmyeloid leukocytes, BM monocytes from saline (SAL)- or LPS-treated mice, cultured BMMs, and classical or alternative activated BMMs (CAMs and AAMs, respectively). Statistical analysis: one-way ANOVA $\left.F_{(5,13)}=26.13, p<0.0001\right)$ followed by HolmSidak's post hoc test, ${ }^{* *} p<0.01 ;{ }^{* * *} p<0.0001 ; n=3-4$ /group. $D$, Infarct volumes of mice receiving $B M M(+7 \mathrm{~h}$ post-MCA0), BMMs that underwent either classical (CAMs) or alternative (AAMs) activation, or BMMs that were polarized to MDSCs were not different from those of mice treated with saline (SAL) ( $n=4-10$ mice/group). Statistical analysis: Kruskal-Wallis ( $\mathrm{H}=2.833$, $p=0.7257)$. $\boldsymbol{E}$, Mice receiving monocytes (7 h after MCAO) isolated from $\mathrm{IL}-10^{-1-}$, iNOS ${ }^{-1-}$, or $\mathrm{CCR}^{-1-}$ LPS-preconditioned mice, but not from COX2 ${ }^{-1-}$ LPS-preconditioned mice, had larger infarcts compared with the mice receiving monocytes isolated from WT LPS-preconditioned mice ( $n=6-8$ mice/group). AT, Adoptive transfer. Statistical analysis: one-way ANOVA $\left(F_{(3,32)}=4.175\right.$, $p=0.0040$ ) followed by Holm-Sidak's post hoc test, ${ }^{*} p<0.05$.

vehicle (PBS) ex vivo before injecting them $\left(5 \times 10^{5}\right.$ cell, i.v. $)$ into mice $7 \mathrm{~h}$ after MCAO. Mice receiving LPS-treated monocytes showed smaller infarcts $(-55 \pm 10 \%$; $p<0.05)$ than mice receiving $\mathrm{PBS}$ treated monocytes (Fig. $7 A$ ), a protective effect comparable to that observed in LPS-PC mice (Fig. 2D). Importantly, the protection was lost when LPS-stimulated monocytes were lysed (Fig. 7A). The reduction in brain injury was accompa-

nied by a better neurological outcome as assessed by the tape test $72 \mathrm{~h}$ after occlusion (Fig. 7B). As in monocytes isolated from LPS-treated mice, monocytes exposed in vitro to LPS for $2 \mathrm{~h}$ showed increased $I L-10$ and Nos2 expression (Fig. $7 C$ ). To test whether the protective activity could also be elicited by human monocytes, we exposed purified human peripheral blood monocytes to saline or LPS for $2 \mathrm{~h}$ and transferred them into mice that underwent stroke as described above. Transfer of human monocytes that were exposed to LPS, but not saline, significantly reduced infarct volumes after MCAO (Fig. 7D). The degree of reduction was comparable to that observed in mice receiving murine LPS-treated monocytes compared with mice receiving either human or mouse PBS monocytes ( $-45 \pm 10 \%$ vs $-55 \pm 10 \%$, respectively; $p>0.05$ ).

We also sought to determine whether adoptively transferred monocytes exposed to LPS ex vivo were recruited to the brain and meninges. BM monocytes from GFP transgenic mice were exposed to vehicle (PBS) or LPS and transferred into mice $7 \mathrm{~h}$ after MCAO. We found that both PBS- and LPS-primed monocytes were present in the meninges, but not in the brain, after stroke (Fig. 7E). Transferred monocytes were mainly seen intravascularly or perivascularly in vessels in or near the superior sagittal sinus. These findings suggest that the presence of MMøs in the meninges is not sufficient to confer neuroprotection and priming of the monocytes by LPS is also needed.

\section{LPS-primed monocytes suppress inflammatory cytokines in the meninges}

To address whether adoptive transfer of protective monocytes would alter the inflammatory response in meninges after stroke, we conducted mRNA analysis of inflammatory molecules involved in leukocyte chemotaxis $(\mathrm{Ccl} 2, \mathrm{Ccl} 5, \mathrm{Cxcl} 1$, $\mathrm{Cxcl} 3, \mathrm{Cxcl} 5, \mathrm{Cxcl10}$, and $\mathrm{Cxcl12}$ ) and survival/activation (Csf1, Csf2, and Csf3) in the meninges of mice receiving LPSprimed monocytes $48 \mathrm{~h}$ after MCAO. All inflammatory molecules were upregulated in the meninges except for Ccl5 (Fig. $7 F$ ). The neutrophil regulatory factors $C x c l 5, C s f 2$, and $C s f 3$ and the lymphocyte regulatory factor $\mathrm{Cxcl} 10$ were significantly decreased in mice receiving LPS-primed monocytes. These data indicate that LPS-primed monocytes in the meninges suppress the postischemic expression of inflammatory cytokines involved in leukocyte trafficking to the brain.

\section{Discussion}

We have found that LPS-PC leads to accumulation of "inflammatory" MMøs in the brains and meninges of preconditioned animals and that LPS-PC monocytes are sufficient to induce neuroprotection after adoptive transfer. Although previous studies have focused on the effects of LPS-PC on gene regulation within the brain (Stevens et al., 2011), here, we investigated whether LPS-PC induces a peripheral immune response that contributes to cerebral ischemic tolerance and modifies stroke outcome. We found that monocytes are recruited to brain and meninges after LPS-PC. This was specific for monocytes because neutrophils did not accumulate in the brain or meninges after LPS-PC even though their frequency was strongly increased in the peripheral blood. Monocytes and/or MMøs were observed at intravascular and perivascular sites, raising the possibility that they may signal to vascular and parenchymal cells, leading to an altered immune response after cerebral ischemia. We did not address whether this response was specific to brain and meninges, but findings that MMøs are increased in the kidney after LPS-PC (Hato et al., 2018) could indicate that similar immune cell recruitment is observed in other organs. 
A
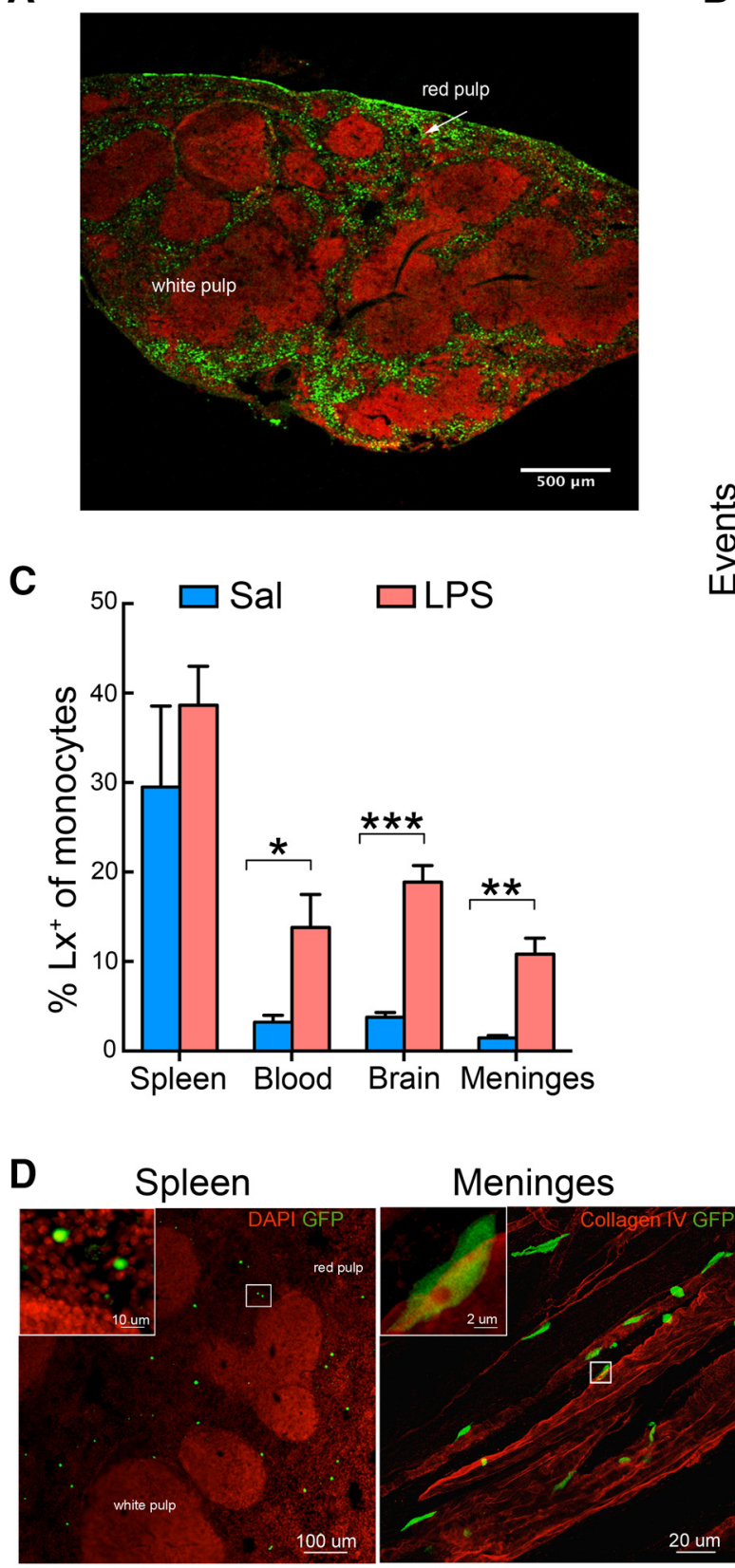

E

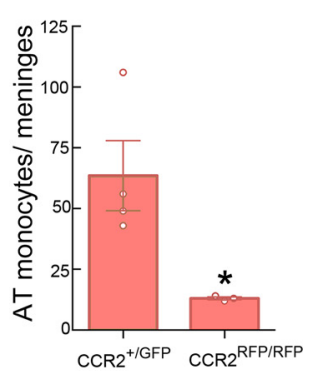

$\mathbf{F}$

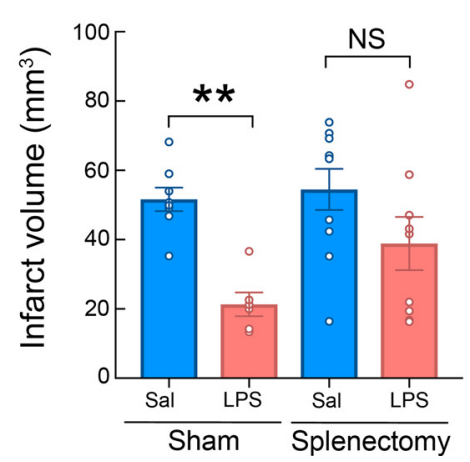

G

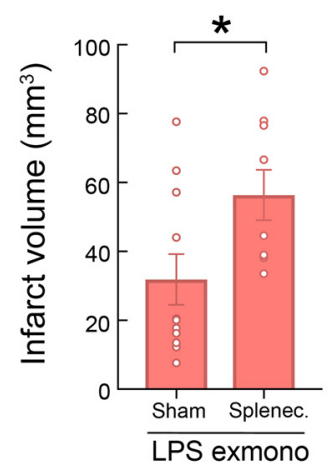

Figure 5. LPS induces trafficking of splenic monocytes to the brain and meninges. $\boldsymbol{A}$, Representative image of the localization of $\mathrm{Lx}^{+}$in the spleen $24 \mathrm{~h}$ after intrasplenic injection $\left(1.8 \times 10^{9}\right.$ particles). The beads (green) accumulated in the $\mathrm{MZ}$ and subcapsular red pulp. Fluorescent nuclear staining with the T0-PRO-3 (red) was used to reveal the structural anatomy of the spleen (transverse section). B, C, Representative flow cytometry histograms $(\boldsymbol{B})$ and quantification $(\boldsymbol{C})$ of MMøs (CD115 ${ }^{+}$cells) showing
Importantly, we observed that monocytes isolated from the $\mathrm{BM}$ of mice that underwent LPS-PC were able to confer robust neuroprotection when adoptively transferred to naive mice $7 \mathrm{~h}$ after MCAO, indicating that monocytes are sufficient to induce ischemic tolerance. Adoptive transfer of monocytes isolated from saline-treated animals did not alter stroke outcome, suggesting that LPS-induced gene expression is required to establish the protective phenotype. In contrast, adoptively transferred neutrophils isolated from the LPSpreconditioned animals or in vitro differentiated CAMs, AAMs, and MDSCs were not able to confer neuroprotection. Therefore, the capacity to confer protection from ischemic brain injury is restricted to a selected monocyte subpopulation.

Our data also show that the protective phenotype of adoptively transferred monocytes is dependent on the expression of CCR2, IL-10, and iNOS. CCR2 is

\section{$\leftarrow$}

the percentage of MMøs containing $\mathrm{Lx}^{+}$in the spleen, blood, brain, and meninges $24 \mathrm{~h}$ after either LPS-PC or saline injection in mice ( $n=3-4$ /group). Total number of $\mathrm{Lx}^{+} \mathrm{CD} 115^{+}$cells in the brain and meninges are given in brackets. $\mathrm{Lx}^{+}$was injected into the spleen $7 \mathrm{~h}$ after saline or LPS treatment. Statistical analysis: unpaired two-tailed Student's $t$ test, blood $\left(t=2.77, \mathrm{df}=6,{ }^{*} p=0.0321\right)$, brain $(t=7.81, \mathrm{df}=6$, $\left.{ }^{* * *} p=0.0002\right)$ and meninges $\left(t=5.22, \mathrm{df}=6,{ }^{* *} p=\right.$ $0.0019)$. $\boldsymbol{D}$, Representative image of the spleen (left) and meninges (right) from mice that underwent $24 \mathrm{~h}$ of MCAO and received GFP ${ }^{+}$monocytes $\left(5 \times 10^{5}\right.$ cells, i.v. $)$ isolated from LPS-preconditioned mice at $7 \mathrm{~h}$ after MCA0. Transverse section of the spleen was stained with DAPI (red) for nuclear staining. Adoptively transferred monocytes accumulated in the red pulp of the spleen. In the meninges, monocytes were associated with meningeal blood vessel revealed by collagen IV (red) immunohistochemistry. $\boldsymbol{E}$, Quantification of adoptively transferred monocytes (AT) in the meninges of WT mice $24 \mathrm{~h}$ after MCA0. Mice received either $\mathrm{GFP}^{+} \mathrm{CCR}^{+/+}$monocytes $\left(\mathrm{CCRR}^{+/ / G P P}\right)$ or RFP ${ }^{+} \mathrm{CCR}^{-1-}$ monocytes (CCR2 $2^{\mathrm{RFP} / \mathrm{RPP}}$; $5 \times 10^{5}$ cells, i.v.) isolated from GFP-WT or CCR2 ${ }^{\text {RFP/RFP }}$ LPSpreconditioned mice, respectively. GFP or RFP fluorescence was used to track transferred BM monocytes ( $n=4$ mice/ group). The genetic deletion of (CR2 resulted in a decrease of meninge-associated monocytes. Statistical analysis: unpaired two-tailed Student's $t$ test, blood $\left(t=2.96, \mathrm{df}=5,{ }^{*} p=\right.$ 0.0315). $\boldsymbol{F}$, Infarct volume analysis in either sham-operated (Sham) or splenectomized (Splenectomy) mice that received saline or LPS treatment (i.p.) $24 \mathrm{~h}$ before MCA0. Shamoperated mice treated with LPS showed reduction of infarct volume, whereas no statistical significances were observed between splenectomized mice treated with saline (SAL) or LPS ( $n=6-10$ mice/group). Statistical analysis: one-way ANOVA $\left(F_{(3,29)}=5.608, p=0.0037\right)$ followed by Bonferroni's post hoc test, ${ }^{* *} p<0.05$. G, Infarct volume analysis in either sham-operated (Sham) or splenectomized (Splenectomy) mice that received ex vivo LPS-primed monocytes $7 \mathrm{~h}$ after MCAO (LPS exmono). Sham-operated mice had significant smaller infarcts than splenectomized mice ( $n=9-11$ mice/ group). Statistical analysis: Mann-Whitney test $(U=0.03$ $\left.{ }^{*} p<0.05\right)$. 
the major chemokine receptor involved in monocyte infiltration after brain ischemia (Gliem et al., 2012; Garcia-Bonilla et al., 2016). Here, we show that CCR2 is also required for meningeal recruitment of monocytes. Interestingly, several studies have reported increased injury after $\mathrm{MCAO}$ in CCR2 ${ }^{-1-}$ mice, which lack circulating inflammatory monocytes (Gliem et al., 2012; Chu et al., 2015; GarciaBonilla et al., 2016; Wattananit et al., 2016), an observation consistent with a neuroprotective activity of monocytes recruited to the ischemic lesion. Furthermore, hypoxic and ischemic PC are also dependent on CCL2/CCR2 signaling (Rehni and Singh, 2012; Stowe et al., 2012), indicating that recruitment of protective monocytes might be a global mechanism underlying brain PC. IL-10 has been proposed as a necessary component of ischemic tolerance in the myocardium (Cai et al., 2012) and is upregulated in the plasma, but not the brain, after LPS-PC (Vartanian et al., 2011). These results are consistent with a role for IL-10 production in circulating immune cells, possibly monocytes, as observed in our study. Previous studies have identified iNOS-derived NO as an essential mediator of ischemic and LPS-PC (Kawano et al., 2007; Kunz et al., 2007). Our results support these previous findings and support the hypothesis that monocytederived NO contributes to ischemic tolerance in LPS-PC.

Using labeling of splenic monocyte/ macrophages by subcapsular $\mathrm{Lx}^{+}$injection, we also found that LPS treatment mobilizes monocytes from the spleen into circulation and that splenic monocytes became associated with brain and meninges. The contribution of splenic monocytes to stroke pathology has been a matter of debate. Although several studies have shown a role for the spleen, specifically splenic monocytes, in promoting ischemic brain injury (Ajmo et al., 2008; Ostrowski et al., 2012; Seifert et al., 2012; Dotson et al., 2015), others failed to do so (Kim et al., 2014; Zierath et al., 2017). We did not specifically address the deleterious effects of splenic monocytes in brain ischemia, but our studies in splenectomized mice support the conclusion that splenic monocytes, when exposed to a systemic PC stimulus such as LPS, can be protective against ischemic brain injury. In addition, the spleen was required to unleash the neuroprotective capacity of adoptively transferred LPS-preconditioned monocytes. Several potential mechanisms could account for this finding. First, monocytes may need to home to the spleen to become licensed to exhibit their neuroprotective phenotype.

A

B
Meninges
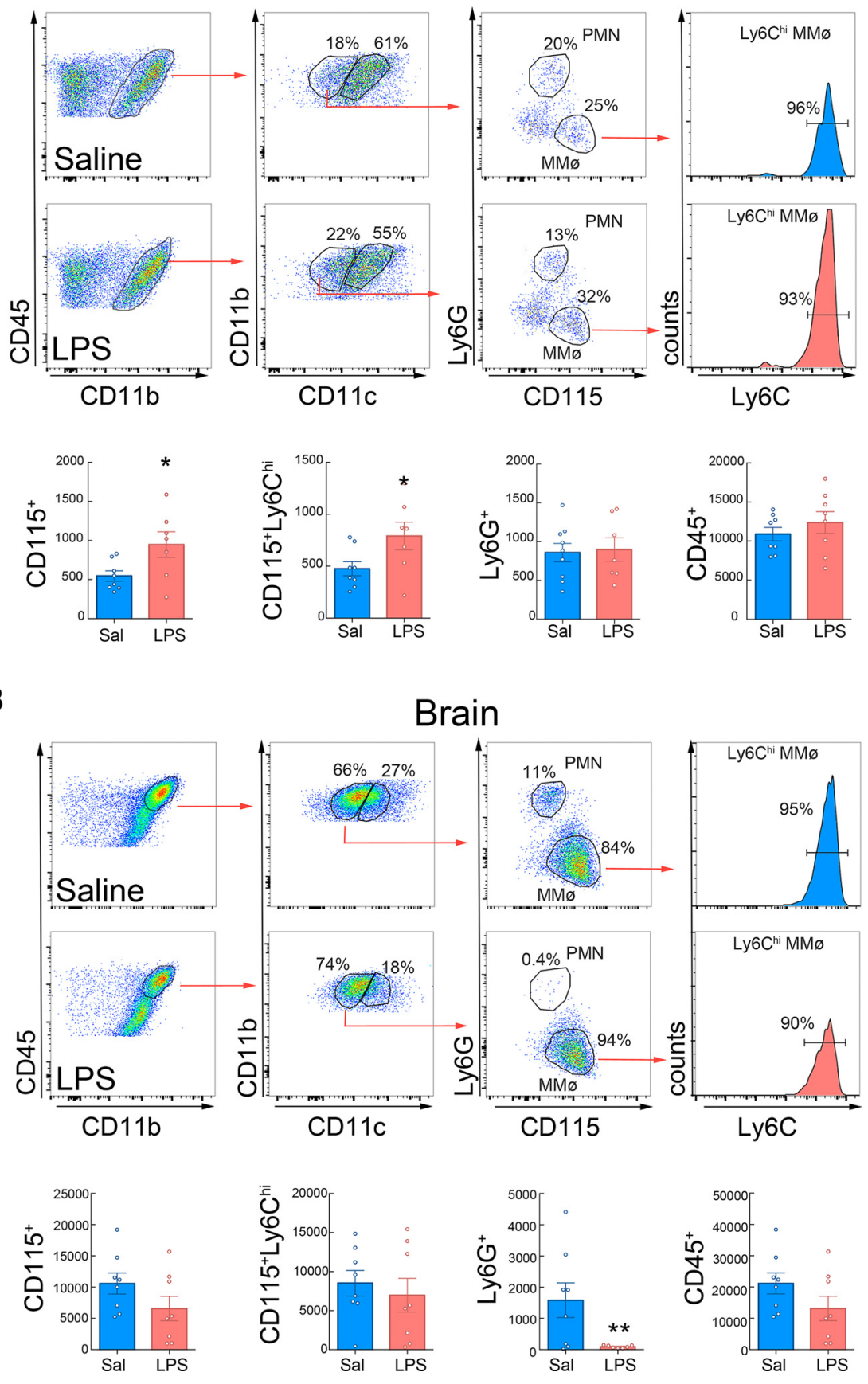

Figure 6. LPS-PC increases meningeal monocyte/macrophages and decreases brain neutrophil recruitment after MCA0. Flow cytometry analysis of immune cell infiltration in the meninges $(\boldsymbol{A})$ and the brain $(\boldsymbol{B})$ of saline or LPS-preconditioned mice $48 \mathrm{~h}$ after MCAO ( $n=8$ mice/group). Flow cytometry plots depict gating strategy. Infiltrating leukocytes (CD45 ${ }^{\text {hi }}$ ) were phenotyped as MMøs (MMø) by high expression of CD11b and CD115 and low expression of CD11 c and Ly6G (CD115 ${ }^{+}$cells). Inflammatory MMø were subclassified by high Ly6C expression (CD115 ${ }^{+}$Ly6C ${ }^{\text {hi }}$ ). Neutrophils (PMN) were identified by high expression of CD11b and Ly6G and low expression of CD11C and CD115 (Ly6G ${ }^{+}$cells). A, Graph plots show increased inflammatory MMø (CD115 ${ }^{+}$and $\mathrm{CD}_{115}{ }^{+}$Ly6C $^{\text {hi }}$ cells) in the meninges of LPS-preconditioned mice following MCA0. Statistical analysis: CD115 ${ }^{+}$, unpaired twotailed Student's $t$ test, blood $\left(t=2.381, \mathrm{df}=13,{ }^{*} p=0.0332\right) ; \mathrm{CD}_{115}{ }^{+}$Ly6C ${ }^{\text {hi }}$, unpaired two-tailed Student's $t$ test, blood ( $t=$ 2.186, df $\left.=13,{ }^{*} p=0.0477\right) ; B$. Graph plots show decreased brain neutrophils (PMN) in LPS-preconditioned mice following MCA0. Statistical analysis: Ly6G ${ }^{+}$, unpaired two-tailed Student's $t$ test, blood $\left(t=2.502, \mathrm{df}=13,{ }^{*} p=0.0265\right)$.

Similar licensing has been observed in other models. For example, it has been shown that interaction with splenic stromal cells is required to elicit immunosuppressor functions in DCs (Zhang et al., 2004; Xu et al., 2012). Alternatively, adoptively transferred 
A

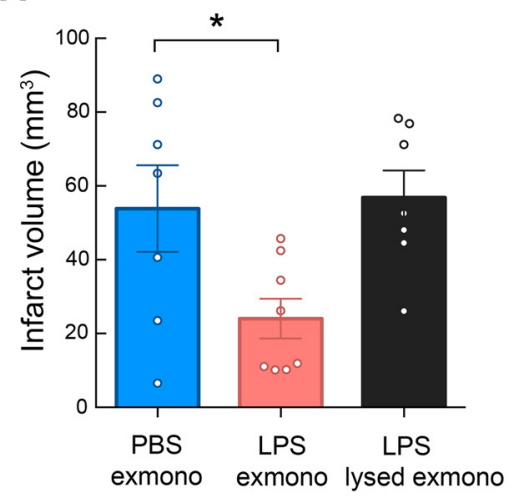

B

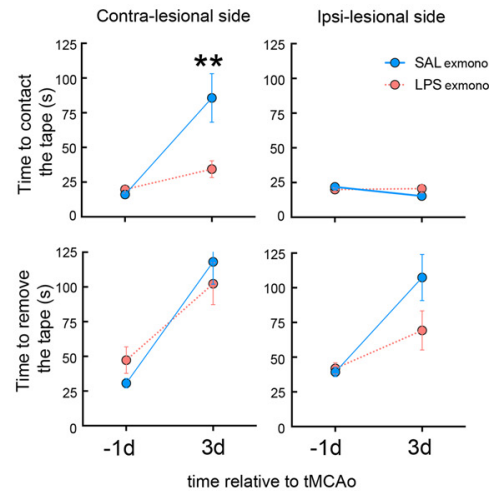

D
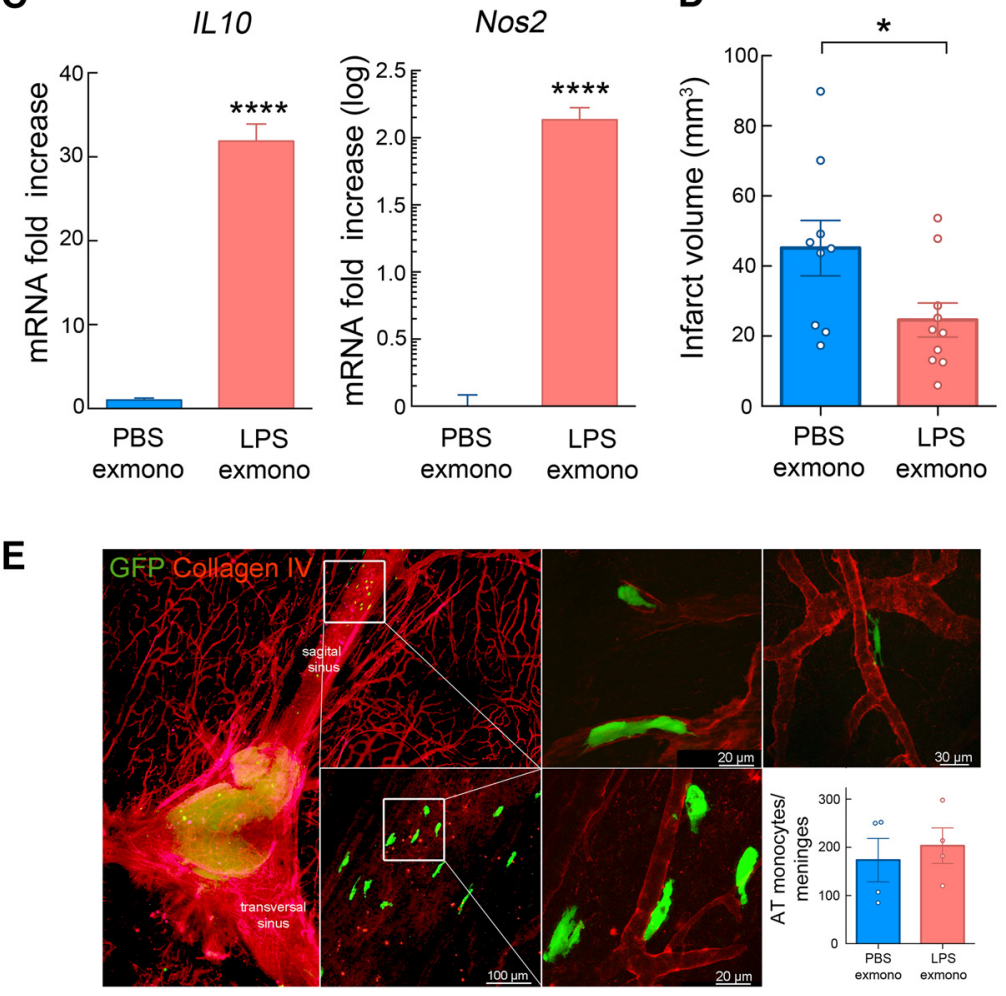

$\mathbf{F}$
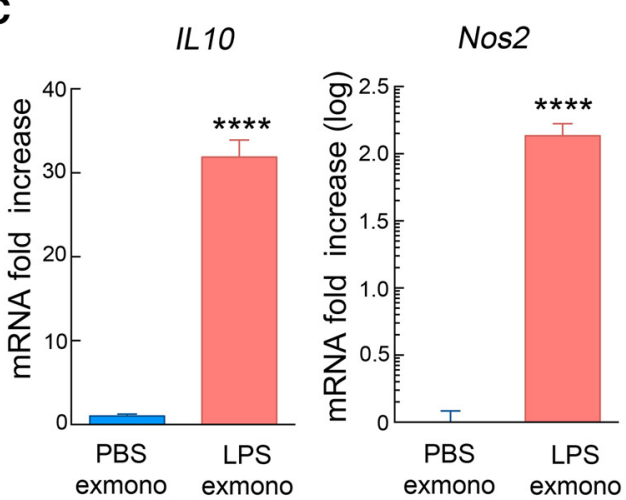

exmono exmono

\section{$E$}

\section{Neutrophil regulatory factors}

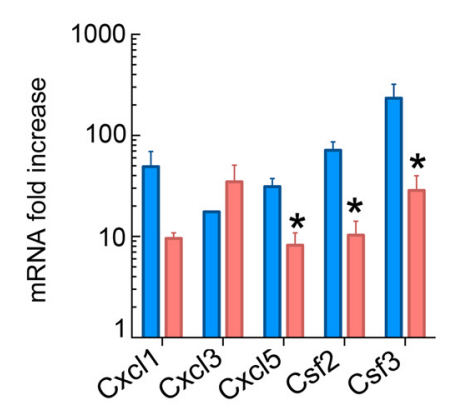

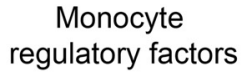

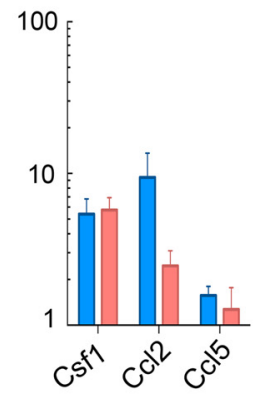

Lymphocyte regulatory factors

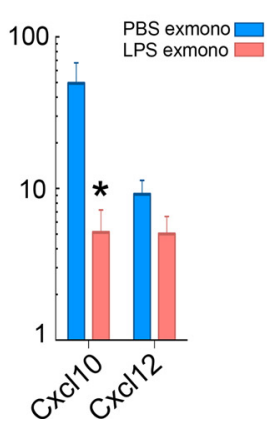

Figure 7. Adoptive transfer of ex vivo LPS-primed mouse and human monocytes exerts protection in recipient mice after MCAO. $\boldsymbol{A}$, Infarct volume analysis in mice that adoptively received ex vivo PBS-treated monocytes (PBS exmono), LPS-treated (LPS; 100 $\mathrm{ng} / \mathrm{ml}, 2 \mathrm{~h}$ ) monocytes (LPS exmonno), or lysed LPS-treated monocytes $7 \mathrm{~h}$ after MCAO (LPS lysed exmono). Mice receiving ex vivo LPS-primed monocytes showed reduction of infarct volume ( $n=7-8$ mice/group). Statistical analysis: one-way ANOVA $F_{(2,19)}=$ 4.933, $p=0.0188$ ), followed by Bonferroni's post hoc test, ${ }^{*} p<0.05$. $B$, Assessment of sensorimotor function by tape test monocytes might instruct other immune cells in the spleen to change their inflammatory phenotype. It has been reported that adoptively transferred Ly6 $\mathrm{C}^{\text {hi }}$ monocytes can transform into marginal zone (MZ) macrophages (A-Gonzalez et al., 2013). The macrophages in the $M Z$ and subcapsular red pulp are strategically placed to interact with splenic immune cells and bloodborne mediators produced by a systemic PC stimulus or after stroke. It is therefore possible that splenic MMøs, depending on their activation state, instruct other splenic immune cells poised to participate in the inflammatory response after stroke to exhibit a proinflammatory or anti-inflammatory phenotype.

Our study also identifies the meninges as a key immunoregulatory compartment involved in PC and ischemic brain injury. Whereas protective MMøs were found in both brain and meninges after LPS-PC, they were only found in the meninges after adoptive transfer. These findings emphasize a potential role for the meninges

\section{$\leftarrow$}

performance revealed that mice receiving ex vivo LPS-primed monocytes had reduced latency to contact the tape on the impaired paw (contralesional side) than mice receiving PBStreated monocytes at $3 \mathrm{~d}$ after MCAO ( $n=13$ mice/group). Statistical analysis: two-way ANOVA (interaction, $F_{(1,49)}=$ $7.828, p=0.0073$; treatment, $F_{(1,49)}=5.915, p=0.0187$; time, $F_{(1,49)}=18.4, p<0.0001$ ) followed by Sidak's post hoc test, ${ }^{* *} p<0.01$. C, Quantification of IL-10 and Nos2 (iNOS) expression by qRT-PCR of ex vivo PBS- or LPS-treated monocytes showed upregulation of both genes $2 \mathrm{~h}$ after LPS treatment ( $n=4 /$ group). Statistical analysis: unpaired two-tailed Student's $t$ test, $l L-10\left(t=15.19, \mathrm{df}=6,{ }^{* * * *} p<0.0001\right)$ and $\operatorname{Nos} 2\left(t=16, \mathrm{df}=5,{ }^{* * * *} p<0.0001\right)$. D , Infarct volume analysis in stroke mice receiving ex vivo PBS- or LPS-treated human monocytes $7 \mathrm{~h}$ after MCAO. LPS-primed human monocytes significantly reduced infarct volumes after MCAO compared with mice receiving PBS-primed human monocytes ( $n=9-10$ mice/group). Statistical analysis: unpaired twotailed Student's $t$ test $\left(t=2.267, \mathrm{df}=17,{ }^{*} p=0.0367\right)$. $\boldsymbol{E}$, Histology of the meninges after adoptive transfer of GFP ${ }^{+}$ monocytes ex vivo treated with LPS. Monocytes transferred $7 \mathrm{~h}$ after MCAO were recruited to the meninges, where they associated with vessels (extravascular and intravascular localization) identified by collagen IV expression. The graph shows the number of adoptively transferred monocytes (AT) that accumulated in the meninges at $48 \mathrm{~h}$ MCAO of mice that received either PBS or LPS ex vivo-treated GFP ${ }^{+}$monocytes. No difference in the number of accumulated monocytes was found between groups ( $n=4$ mice/group). Statistical analysis: unpaired two-tailed Student's $t$ test $(t=0.5148, \mathrm{df}=6, p=$ $0.6251) . F$, Gene expression of inflammatory molecules in the meninges of mice receiving ex vivo PBS- or LPS-primed monocytes $48 \mathrm{~h}$ after MCA0. Decreased $\mathrm{CxCl5}$, Csf2, Csf3, and $\mathrm{CxC110}$ gene upregulation was observed in the meninges of mice receiving LPS-primed monocytes ( $n=10-11$ mice/group). Statistical analysis: unpaired two-tailed Student's $t$ test, $C x C 15$ $\left(t=3.6298, \mathrm{df}=7,{ }^{*} p=0.0084\right) ;(\operatorname{cs} 2(t=4.4886, \mathrm{df}=7$, $\left.{ }^{*} p=0.0028\right) ;\left(\operatorname{sf3}\left(t=2.6324, \mathrm{df}=7,{ }^{*} p=0.0337\right)\right.$, and Cxd10 $\left(t=2.7547, \mathrm{df}=7,{ }^{*} p=0.0283\right)$. 
in mediating the neuroprotection afforded by LPS-primed monocytes. We have previously shown that meningeal $\gamma \delta \mathrm{T}$ cells orchestrate immune cell trafficking after ischemic brain injury by promoting neutrophil infiltration into the affected brain parenchyma (Benakis et al., 2016). Here, we demonstrate that meningeal MMøs are capable of dampening the postischemic inflammatory response by suppressing the production of neutrophil-activating and chemotactic factors such as Csf2, Csf3, and $C x c l 5$. We have shown previously that $C s f 3$ is an endothelialderived cytokine responsible for neutrophil activation after stroke (Garcia-Bonilla et al., 2015). Downregulating Csf3 and related cytokines in the meninges may suppress the inflammatory response in neutrophils, thereby limiting their ability to invade the brain parenchyma. Therefore, we propose a reduced infiltration of damping neutrophils as the mechanism by which monocytes protect against ischemic injury.

Another major finding of this study is that monocytes can be primed in vitro to express a neuroprotective phenotype. Therefore, exposure of monocytes to LPS for $2 \mathrm{~h}$ was sufficient to induce their protective potential. Together with the favorable therapeutic window, the quick induction of the neuroprotective phenotype should allow for the development of clinical protocols for stroke therapy. BM mononuclear cells (BMMCs) are increasingly used as a cell therapy for a variety of brain injuries, including stroke, both in preclinical and clinical settings (Rosado-deCastro et al., 2016). Although the identity of the immune cells within the heterogeneous BMMC pool responsible for the protective effects has not been established, one study showed that BMMCs depleted of myeloid cells lost their protective potential after transient MCAO in rats, whereas depletion of the lymphocyte and erythrocyte lineage had no effect (Yang et al., 2016). Similarly, in rats treated with human umbilical cord blood after permanent MCAO, monocytes have been singled out as the protective cell population and peripheral blood CD14 ${ }^{+}$monocytes were sufficient to improve long-term outcome (Womble et al., 2014). The finding that human monocytes can be reprogrammed in vitro to be neuroprotective is of translational and clinical relevance. Although we did not address the mechanism by which human PC monocytes exert their protective effects, it is likely that their effector mechanisms are also dependent upon IL-10 and NO. Importantly, iNOS and IL-10 are upregulated in LPS-treated human monocytes and human IL-10 shows cross-species activity on mouse cells (Tan et al., 1993).

In summary, our study identifies a distinct population of splenic monocytes as key effector cells in the profound protective effect afforded by LPS-PC. After exposure to LPS either in vitro or in vivo, these cells are able to modulate meningeal and parenchymal immune responses after MCAO, limiting ischemic injury and improving functional outcome with a clinically relevant therapeutic window. Furthermore, our findings demonstrate that in vitro priming of monocytes with TLR4 agonists triggers protective potential against ischemic brain injury and raise the possibility that similar approaches could be used to enhance the effectiveness of monocytebased cell therapies in ischemic stroke patients.

\section{References}

A-Gonzalez N, et al. (2013) The nuclear receptor LXR $\alpha$ controls the functional specialization of splenic macrophages. Nat Immunol 14:831-839. CrossRef Medline

Ahmed SH, He YY, Nassief A, Xu J, Xu XM, Hsu CY, Faraci FM (2000) Effects of lipopolysaccharide priming on acute ischemic brain injury. Stroke 31:193-199. CrossRef Medline

Ajmo CT Jr, Vernon DO, Collier L, Hall AA, Garbuzova-Davis S, Willing A,
Pennypacker KR (2008) The spleen contributes to stroke-induced neurodegeneration. J Neurosci Res 86:2227-2234. CrossRef Medline

Arnold L, Henry A, Poron F, Baba-Amer Y, van Rooijen N, Plonquet A, Gherardi RK, Chazaud B (2007) Inflammatory monocytes recruited after skeletal muscle injury switch into antiinflammatory macrophages to support myogenesis. J Exp Med 204:1057-1069. CrossRef Medline

Auffray C, Fogg D, Garfa M, Elain G, Join-Lambert O, Kayal S, Sarnacki S, Cumano A, Lauvau G, Geissmann F (2007) Monitoring of blood vessels and tissues by a population of monocytes with patrolling behavior. Science 317:666-670. CrossRef Medline

Banks WA, Robinson SM (2010) Minimal penetration of lipopolysaccharide across the murine blood-brain barrier. Brain Behav Immun 24:102109. CrossRef Medline

Bauer P, Welbourne T, Shigematsu T, Russell J, Granger DN (2000) Endothelial expression of selectins during endotoxin preconditioning. Am J Physiol Regul Integr Comp Physiol 279:R2015-R2021. CrossRef Medline

Benakis C, Brea D, Caballero S, Faraco G, Moore J, Murphy M, Sita G, Racchumi G, Ling L, Pamer EG, Iadecola C, Anrather J (2016) Commensal microbiota affects ischemic stroke outcome by regulating intestinal $\gamma \delta \mathrm{T}$ cells. Nat Med 22:516-523. CrossRef Medline

Biswas SK, Lopez-Collazo E (2009) Endotoxin tolerance: new mechanisms, molecules and clinical significance. Trends Immunol 30:475-487. CrossRef Medline

Bronte V (2009) Myeloid-derived suppressor cells in inflammation: uncovering cell subsets with enhanced immunosuppressive functions. Eur J Immunol 39:2670-2672. CrossRef Medline

Cai ZP, Parajuli N, Zheng X, Becker L (2012) Remote ischemic preconditioning confers late protection against myocardial ischemia-reperfusion injury in mice by upregulating interleukin-10. Basic Res Cardiol 107:277. CrossRef Medline

Chu HX, Broughton BR, Kim HA, Lee S, Drummond GR, Sobey CG (2015) Evidence that Ly6Chi monocytes are protective in acute ischemic stroke by promoting M2 macrophage polarization. Stroke 46:1929-1937. CrossRef Medline

Corraliza IM, Campo ML, Soler G, Modolell M (1994) Determination of arginase activity in macrophages: a micromethod. J Immunol Methods 174:231-235. CrossRef Medline

Dotson AL, Wang J, Saugstad J, Murphy SJ, Offner H (2015) Splenectomy reduces infarct volume and neuroinflammation in male but not female mice in experimental stroke. J Neuroimmunol 278:289-298. CrossRef Medline

Dunning MJ, Smith ML, Ritchie ME, Tavaré S (2007) beadarray: r classes and methods for illumina bead-based data. Bioinformatics 23:2183-2184. CrossRef Medline

Forghani P, Khorramizadeh MR, Waller EK (2012) Natural suppressor cells; past, present and future. Front Biosci (Elite Ed) 4:1237-1245. Medline

Garcia-Bonilla L, Benakis C, Moore J, Iadecola C, Anrather J (2014a) Immune mechanisms in cerebral ischemic tolerance. Front Neurosci 8:44. CrossRef Medline

Garcia-Bonilla L, Moore JM, Racchumi G, Zhou P, Butler JM, Iadecola C, Anrather J (2014b) Inducible nitric oxide synthase in neutrophils and endothelium contributes to ischemic brain injury in mice. J Immunol 193:2531-2537. CrossRef Medline

Garcia-Bonilla L, Racchumi G, Murphy M, Anrather J, Iadecola C (2015) Endothelial CD36 contributes to postischemic brain injury by promoting neutrophil activation via CSF3. J Neurosci 35:14783-14793. CrossRef Medline

Garcia-Bonilla L, Faraco G, Moore J, Murphy M, Racchumi G, Srinivasan J, Brea D, Iadecola C, Anrather J (2016) Spatio-temporal profile, phenotypic diversity, and fate of recruited monocytes into the post-ischemic brain. J Neuroinflammation 13:285. CrossRef Medline

Geissmann F, Jung S, Littman DR (2003) Blood monocytes consist of two principal subsets with distinct migratory properties. Immunity 19:71-82. CrossRef Medline

Gliem M, Mausberg AK, Lee JI, Simiantonakis I, van Rooijen N, Hartung HP, Jander S (2012) Macrophages prevent hemorrhagic infarct transformation in murine stroke models. Ann Neurol 71:743-752. CrossRef Medline

Hato T, Zollman A, Plotkin Z, El-Achkar TM, Maier BF, Pay SL, Dube S, Cabral P, Yoshimoto M, McClintick J, Dagher PC (2018) Endotoxin preconditioning reprograms $\mathrm{S} 1$ tubules and macrophages to protect the kidney. J Am Soc Nephrol 29:104-117. CrossRef Medline

Highfill SL, Rodriguez PC, Zhou Q, Goetz CA, Koehn BH, Veenstra R, Taylor PA, Panoskaltsis-Mortari A, Serody JS, Munn DH, Tolar J, Ochoa AC, Blazar BR (2010) Bone marrow myeloid-derived suppressor cells (MDSCs) 
inhibit graft-versus-host disease (GVHD) via an arginase-1-dependent mechanism that is upregulated by interleukin-13. Blood 116:5738-5747. CrossRef Medline

Huang B, Pan PY, Li Q, Sato AI, Levy DE, Bromberg J, Divino CM, Chen SH (2006) Gr-1+CD115+ immature myeloid suppressor cells mediate the development of tumor-induced T regulatory cells and T-cell anergy in tumor-bearing host. Cancer Res 66:1123-1131. CrossRef Medline

Iadecola C, Anrather J (2011) Stroke research at a crossroad: asking the brain for directions. Nat Neurosci 14:1363-1368. CrossRef Medline

Jackman K, Kunz A, Iadecola C (2011) Modeling focal cerebral ischemia in vivo. Methods Mol Biol 793:195-209. CrossRef Medline

Kawano T, Kunz A, Abe T, Girouard H, Anrather J, Zhou P, Iadecola C (2007) iNOS-derived NO and nox2-derived superoxide confer tolerance to excitotoxic brain injury through peroxynitrite. J Cereb Blood Flow Metab 27:1453-1462. CrossRef Medline

Kilkenny C, Browne W, Cuthill IC, Emerson M, Altman DG; National Centre for the Replacement, Refinement and Reduction of Amimals in Research (2011) Animal research: reporting in vivo experiments-the ARRIVE guidelines. J Cereb Blood Flow Metab 31:991-993. CrossRef Medline

Kim E, Yang J, D Beltran CD, Cho S (2014) Role of spleen-derived monocytes/macrophages in acute ischemic brain injury. J Cereb Blood Flow Metab 34:1411-1419. CrossRef Medline

Kirino T (2002) Ischemic tolerance. J Cereb Blood Flow Metab 22:12831296. CrossRef Medline

Kunz A, Park L, Abe T, Gallo EF, Anrather J, Zhou P, Iadecola C (2007) Neurovascular protection by ischemic tolerance: role of nitric oxide and reactive oxygen species. J Neurosci 27:7083-7093. CrossRef Medline

Liesz A, Dalpke A, Mracsko E, Antoine DJ, Roth S, Zhou W, Yang H, Na SY, Akhisaroglu M, Fleming T, Eigenbrod T, Nawroth PP, Tracey KJ, Veltkamp R (2015) DAMP signaling is a key pathway inducing immune modulation after brain injury. J Neurosci 35:583-598. CrossRef Medline

Lin HY, Huang CC, Chang KF (2009) Lipopolysaccharide preconditioning reduces neuroinflammation against hypoxic ischemia and provides longterm outcome of neuroprotection in neonatal rat. Pediatr Res 66:254259. CrossRef Medline

Livak KJ, Schmittgen TD (2001) Analysis of relative gene expression data using real-time quantitative PCR and the 2(-delta delta $\mathrm{C}(\mathrm{T})$ ) method. Methods 25:402-408. CrossRef Medline

Louveau A, Kipnis J (2015) Dissection and immunostaining of mouse whole-mount meninges. Protocol Exchange. Nature Publishing Group.

MacMicking JD, Nathan C, Hom G, Chartrain N, Fletcher DS, Trumbauer M, Stevens K, Xie QW, Sokol K, Hutchinson N (1995) Altered responses to bacterial infection and endotoxic shock in mice lacking inducible nitric oxide synthase. Cell 81:641-650. CrossRef Medline

Manthey CL, Vogel SN (1994) Elimination of trace endotoxin protein from rough chemotype LPS. Innate Immunity 1:84-91.

Marsh BJ, Stenzel-Poore MP (2008) Toll-like receptors: novel pharmacological targets for the treatment of neurological diseases. Curr Opin Pharmacol 8:8-13. CrossRef Medline

Marsh B, Stevens SL, Packard AE, Gopalan B, Hunter B, Leung PY, Harrington CA, Stenzel-Poore MP (2009a) Systemic lipopolysaccharide protects the brain from ischemic injury by reprogramming the response of the brain to stroke: a critical role for IRF3. J Neurosci 29:9839-9849. CrossRef Medline

Marsh BJ, Williams-Karnesky RL, Stenzel-Poore MP (2009b) Toll-like receptor signaling in endogenous neuroprotection and stroke. Neuroscience 158:1007-1020. CrossRef Medline

Miró-Mur F, Pérez-de-Puig I, Ferrer-Ferrer M, Urra X, Justicia C, Chamorro A, Planas AM (2016) Immature monocytes recruited to the ischemic mouse brain differentiate into macrophages with features of alternative activation. Brain Behav Immun 53:18-33. CrossRef Medline

Morham SG, Langenbach R, Loftin CD, Tiano HF, Vouloumanos N, Jennette JC, Mahler JF, Kluckman KD, Ledford A, Lee CA, Smithies O (1995) Prostaglandin synthase 2 gene disruption causes severe renal pathology in the mouse. Cell 83:473-482. CrossRef Medline

Muzio M, Bosisio D, Polentarutti N, D’amico G, Stoppacciaro A, Mancinelli R, van't Veer C, Penton-Rol G, Ruco LP, Allavena P, Mantovani A (2000) Differential expression and regulation of toll-like receptors (TLR) in human leukocytes: selective expression of TLR3 in dendritic cells. J Immunol 164:5998-6004. CrossRef Medline

Nahrendorf M, Swirski FK, Aikawa E, Stangenberg L, Wurdinger T, Figueiredo JL, Libby P, Weissleder R, Pittet MJ (2007) The healing myo- cardium sequentially mobilizes two monocyte subsets with divergent and complementary functions. J Exp Med 204:3037-3047. CrossRef Medline

Nahrendorf M, Pittet MJ, Swirski FK (2010) Monocytes: protagonists of infarct inflammation and repair after myocardial infarction. Circulation 121:2437-2445. CrossRef Medline

Ostrand-Rosenberg S (2010) Myeloid-derived suppressor cells: more mechanisms for inhibiting antitumor immunity. Cancer Immunol Immunother 59:1593-1600. CrossRef Medline

Ostrowski RP, Schulte RW, Nie Y, Ling T, Lee T, Manaenko A, Gridley DS, Zhang JH (2012) Acute splenic irradiation reduces brain injury in the rat focal ischemic stroke model. Transl Stroke Res 3:473-481. CrossRef Medline

Pradillo JM, Fernández-López D, García-Yébenes I, Sobrado M, Hurtado O, Moro MA, Lizasoain I (2009) Toll-like receptor 4 is involved in neuroprotection afforded by ischemic preconditioning. J Neurochem 109:287294. CrossRef Medline

Rehni AK, Singh TG (2012) Involvement of CCR-2 chemokine receptor activation in ischemic preconditioning and postconditioning of brain in mice. Cytokine 60:83-89. CrossRef Medline

Reich M, Liefeld T, Gould J, Lerner J, Tamayo P, Mesirov JP (2006) GenePattern 2.0. Nat Genet 38:500-501. CrossRef Medline

Ritchie ME, Phipson B, Wu D, Hu Y, Law CW, Shi W, Smyth GK (2015) limma powers differential expression analyses for RNA-sequencing and microarray studies. Nucleic Acids Res 43:e47-e47. CrossRef Medline

Rosado-de-Castro PH, de Carvalho FG, de Freitas GR, Mendez-Otero R, Pimentel-Coelho PM (2016) Review of preclinical and clinical studies of bone marrow-derived cell therapies for intracerebral hemorrhage. Stem Cells Int 2016:4617983-18. CrossRef Medline

Rosenzweig HL, Lessov NS, Henshall DC, Minami M, Simon RP, StenzelPoore MP (2004) Endotoxin preconditioning prevents cellular inflammatory response during ischemic neuroprotection in mice. Stroke 35: 2576-2581. CrossRef Medline

Rosenzweig HL, Minami M, Lessov NS, Coste SC, Stevens SL, Henshall DC, Meller R, Simon RP, Stenzel-Poore MP (2007) Endotoxin preconditioning protects against the cytotoxic effects of TNFalpha after stroke: a novel role for TNFalpha in LPS-ischemic tolerance. J Cereb Blood Flow Metab 27:1663-1674. CrossRef Medline

Seifert HA, Leonardo CC, Hall AA, Rowe DD, Collier LA, Benkovic SA, Willing AE, Pennypacker KR (2012) The spleen contributes to stroke induced neurodegeneration through interferon gamma signaling. Metab Brain Dis 27:131-141. CrossRef Medline

Serafini P, De Santo C, Marigo I, Cingarlini S, Dolcetti L, Gallina G, Zanovello P, Bronte V (2004) Derangement of immune responses by myeloid suppressor cells. Cancer Immunol Immunother 53:64-72. CrossRef Medline

Serbina NV, Jia T, Hohl TM, Pamer EG (2008) Monocyte-mediated defense against microbial pathogens. Annu Rev Immunol 26:421-452. CrossRef Medline

Sherman BT, Huang da W, Tan Q, Guo Y, Bour S, Liu D, Stephens R, Baseler MW, Lane HC, Lempicki RA (2007) DAVID knowledgebase: a genecentered database integrating heterogeneous gene annotation resources to facilitate high-throughput gene functional analysis. BMC Bioinformatics 8:426. CrossRef Medline

Shi C, Jia T, Mendez-Ferrer S, Hohl TM, Serbina NV, Lipuma L, Leiner I, Li MO, Frenette PS, Pamer EG (2011) Bone marrow mesenchymal stem and progenitor cells induce monocyte emigration in response to circulating toll-like receptor ligands. Immunity 34:590-601. CrossRef Medline

Singh AK, Jiang Y (2004) How does peripheral lipopolysaccharide induce gene expression in the brain of rats? Toxicology 201:197-207. CrossRef Medline

Smith RM, Lecour S, Sack MN (2002) Innate immunity and cardiac preconditioning: a putative intrinsic cardioprotective program. Cardiovasc Res 55:474-482. CrossRef Medline

Stevens SL, Leung PY, Vartanian KB, Gopalan B, Yang T, Simon RP, StenzelPoore MP (2011) Multiple preconditioning paradigms converge on interferon regulatory factor-dependent signaling to promote tolerance to ischemic brain injury. J Neurosci 31:8456-8463. CrossRef Medline

Stowe AM, Wacker BK, Cravens PD, Perfater JL, Li MK, Hu R, Freie AB, Stüve O, Gidday JM (2012) CCL2 upregulation triggers hypoxic preconditioninginduced protection from stroke. J Neuroinflammation 9:33. CrossRef Medline

Swirski FK, Libby P, Aikawa E, Alcaide P, Luscinskas FW, Weissleder R, Pittet MJ (2007) Ly-6Chi monocytes dominate hypercholesterolemia-asso- 
ciated monocytosis and give rise to macrophages in atheromata. J Clin Invest 117:195-205. CrossRef Medline

Swirski FK, Nahrendorf M, Etzrodt M, Wildgruber M, Cortez-Retamozo V, Panizzi P, Figueiredo JL, Kohler RH, Chudnovskiy A, Waterman P, Aikawa E, Mempel TR, Libby P, Weissleder R, Pittet MJ (2009) Identification of splenic reservoir monocytes and their deployment to inflammatory sites. Science 325:612-616. CrossRef Medline

Swirski FK, Wildgruber M, Ueno T, Figueiredo JL, Panizzi P, Iwamoto Y, Zhang E, Stone JR, Rodriguez E, Chen JW, Pittet MJ, Weissleder R, Nahrendorf M (2010) Myeloperoxidase-rich ly-6C+ myeloid cells infiltrate allografts and contribute to an imaging signature of organ rejection in mice. J Clin Invest 120:2627-2634. CrossRef Medline

Tacke F, Alvarez D, Kaplan TJ, Jakubzick C, Spanbroek R, Llodra J, Garin A, Liu J, Mack M, van Rooijen N, Lira SA, Habenicht AJ, Randolph GJ (2007) Monocyte subsets differentially employ CCR2, CCR5, and CX3CR1 to accumulate within atherosclerotic plaques. J Clin Invest 117:185-194. CrossRef Medline

Tan JC, Indelicato SR, Narula SK, Zavodny PJ, Chou CC (1993) Characterization of interleukin-10 receptors on human and mouse cells. J Biol Chem 268:21053-21059. Medline

Tasaki K, Ruetzler CA, Ohtsuki T, Martin D, Nawashiro H, Hallenbeck JM (1997) Lipopolysaccharide pre-treatment induces resistance against subsequent focal cerebral ischemic damage in spontaneously hypertensive rats. Brain Res 748:267-270. CrossRef Medline

Vartanian KB, Stevens SL, Marsh BJ, Williams-Karnesky R, Lessov NS, Stenzel-Poore MP (2011) LPS preconditioning redirects TLR signaling following stroke: TRIF-IRF3 plays a seminal role in mediating tolerance to ischemic injury. J Neuroinflammation 8:140. CrossRef Medline

Wang F, Birch SE, He R, Tawadros P, Szaszi K, Kapus A, Rotstein OD (2010) Remote ischemic preconditioning by hindlimb occlusion prevents liver ischemic/reperfusion injury. Ann Surg 251:292-299. CrossRef Medline
Wattananit S, Tornero D, Graubardt N, Memanishvili T, Monni E, Tatarishvili J, Miskinyte G, Ge R, Ahlenius H, Lindvall O, Schwartz M, Kokaia Z (2016) Monocyte-derived macrophages contribute to spontaneous longterm functional recovery after stroke in mice. J Neurosci 36:4182-4195. CrossRef Medline

Weischenfeldt J, Porse B (2008) Bone marrow-derived macrophages (BMM): isolation and applications. CSH Protoc 2008:pdb.prot5080. CrossRef Medline

Womble TA, Green S, Shahaduzzaman M, Grieco J, Sanberg PR, Pennypacker KR, Willing AE (2014) Monocytes are essential for the neuroprotective effect of human cord blood cells following middle cerebral artery occlusion in rat. Mol Cell Neurosci 59:76-84. CrossRef Medline

Xu X, Yi H, Guo Z, Qian C, Xia S, Yao Y, Cao X (2012) Splenic stromaeducated regulatory dendritic cells induce apoptosis of activated CD4 T cells via fas ligand-enhanced IFN- $\gamma$ and nitric oxide. J Immunol 188: 1168-1177. CrossRef Medline

Yang B, Parsha K, Schaar K, Xi X, Aronowski J, Savitz SI (2016) Various cell populations within the mononuclear fraction of bone marrow contribute to the beneficial effects of autologous bone marrow cell therapy in a rodent stroke model. Transl Stroke Res 7:322-330. CrossRef Medline

Youn JI, Nagaraj S, Collazo M, Gabrilovich DI (2008) Subsets of myeloidderived suppressor cells in tumor-bearing mice. J Immunol 181:57915802. CrossRef Medline

Zhang M, Tang H, Guo Z, An H, Zhu X, Song W, Guo J, Huang X, Chen T, Wang J, Cao X (2004) Splenic stroma drives mature dendritic cells to differentiate into regulatory dendritic cells. Nat Immunol 5:1124-1133. CrossRef Medline

Zierath D, Shen A, Stults A, Olmstead T, Becker KJ (2017) Splenectomy does not improve long-term outcome after stroke. Stroke 48:497-500. CrossRef Medline 